\title{
Role of microRNA/Epithelial-to-Mesenchymal Transition Axis in the Metastasis of Bladder Cancer
}

\author{
Milad Ashrafizadeh ${ }^{1}$ (D), Kiavash Hushmandi ${ }^{2}$, Mehrdad Hashemi ${ }^{3}$, \\ Mohammad Esmaeil Akbari ${ }^{4}$, Peter Kubatka ${ }^{5}$ D , Mehdi Raei ${ }^{6}{ }^{\mathbb{D}}$, Lenka Koklesova ${ }^{7}$, \\ Md Shahinozzaman ${ }^{8}\left(\mathbb{D}\right.$, Reza Mohammadinejad ${ }^{9}$, Masoud Najafi ${ }^{10}\left(\mathbb{D}\right.$, Gautam Sethi $^{11, *}$, \\ Alan Prem Kumar 11,12 (D) and Ali Zarrabi 13,14,*(D)
}

1 Department of Basic Science, Faculty of Veterinary Medicine, University of Tabriz, Tabriz 5166616471, Iran; dvm.milad73@yahoo.com

2 Department of Food Hygiene and Quality Control, Division of Epidemiology \& Zoonoses, Faculty of Veterinary Medicine, University of Tehran, Tehran 1419963114, Iran; houshmandi.kia7@ut.ac.ir

3 Department of Genetics, Faculty of advanced Science and Technology, Tehran Medical Sciences, Islamic Azad University, Tehran 1916893813, Iran; mhashemi@iautmu.ac.ir

4 Cancer Research Center, Shahid Beheshti University of Medical Sciences, Tehran 1989934148, Iran; profmeakbari@gmail.com

5 Department of Medical Biology and Division of Oncology—Biomedical Center Martin, Jessenius Faculty of Medicine, Comenius University in Bratislava, 03601 Martin, Slovakia; peter.kubatka@uniba.sk

6 Health Research Center, Life Style Institute, Baqiyatallah University of Medical Sciences, Tehran 1435916471, Iran; Mehdi_r_d@yahoo.com

7 Department of Obstetrics and Gynecology, Martin University Hospital and Jessenius Faculty of Medicine in Martin, Comenius University in Bratislava, 03601 Martin, Slovakia; koklesova.lenka@gmail.com

8 Department of Nutrition and Food Science, University of Maryland, College Park, MD 20742, USA; mshahin81@gmail.com

9 Pharmaceutics Research Center, Institute of Neuropharmacology, Kerman University of Medical Sciences, Kerman 55877577, Iran; r.mohammadinjead87@gmail.com

10 Radiology and Nuclear Medicine Department, School of Paramedical Sciences, Kermanshah University of Medical Sciences, Kermanshah 6715847141, Iran; najafi_ma@yahoo.com

11 Department of Pharmacology, Yong Loo Lin School of Medicine, National University of Singapore, Singapore 117600, Singapore; csiapk@nus.edu.sg

12 Cancer Science Institute of Singapore, Centre for Translational Medicine, 14 Medical Drive, \#11-01M, Singapore 117599, Singapore

13 Sabanci University Nanotechnology Research and Application Center (SUNUM), Tuzla, Istanbul 34956, Turkey

14 Center of Excellence for Functional Surfaces and Interfaces (EFSUN), Faculty of Engineering and Natural Sciences, Sabanci University, Tuzla, Istanbul 34956, Turkey

* Correspondence: phcgs@nus.edu.sg (G.S.); alizarrabi@sabanciuniv.edu (A.Z.)

Received: 24 June 2020; Accepted: 5 August 2020; Published: 7 August 2020

\begin{abstract}
Bladder cancer (BC) is the 11th most common diagnosed cancer, and a number of factors including environmental and genetic ones participate in BC development. Metastasis of BC cells into neighboring and distant tissues significantly reduces overall survival of patients with this life-threatening disorder. Recently, studies have focused on revealing molecular pathways involved in metastasis of BC cells, and in this review, we focus on microRNAs (miRNAs) and their regulatory effect on epithelial-to-mesenchymal transition (EMT) mechanisms that can regulate metastasis. EMT is a vital process for migration of $\mathrm{BC}$ cells, and inhibition of this mechanism restricts invasion of BC cells. MiRNAs are endogenous non-coding RNAs with 19-24 nucleotides capable of regulating different cellular events, and EMT is one of them. In BC cells, miRNAs are able to both induce and/or inhibit EMT. For regulation of EMT, miRNAs affect different molecular pathways such as transforming growth factor-beta (TGF- $\beta$ ), Snail, Slug, ZEB1/2, CD44, NSBP1, which are, discussed in detail this review. Besides, miRNA/EMT axis can also be regulated by upstream mediators such as
\end{abstract}


lncRNAs, circRNAs and targeted by diverse anti-tumor agents. These topics are also discussed here to reveal diverse molecular pathways involved in migration of BC cells and strategies to target them to develop effective therapeutics.

Keywords: bladder cancer; metastasis; epithelial-to-mesenchymal transition (EMT); microRNA (miRNA); cancer therapy

\section{Introduction}

Bladder cancer $(\mathrm{BC})$ is among the most common cancers worldwide (11th most common diagnosed cancer) and its global incidence rate is higher in males compared to females ( 9 per 100,000 persons for males and 2.2 per 100,000 persons for females) [1,2]. According to estimates, incidence rate of BC is higher in European countries compared to the average worldwide incidence rate (19.1 for males and 4 for females) [3]. It seems that incidence and mortality of BC are different in various countries based on the risk factors, diagnostic tools and treatment availability as well as data collection strategies [4,5]. $\mathrm{BC}$ has a higher incidence rate in Southern and Western Europe and North America, as well in certain countries in Northern Africa or Western Asia [6].

Although etiology of $\mathrm{BC}$ is not completely understood, a number of factors are considered as risk factors for BC development. The most well-known risk factor is tobacco smoking which is responsible for development of 50\% of BC cases [7]. Occupational exposure to agents such as aromatic amines, polycyclic aromatic hydrocarbons and chlorinated hydrocarbons can be considered as other factors involved in BC development. Genetic mutations are also involved in BC development by enhancing susceptibility into other risk factors [8-10]. Radiation exposure and chlorinating drinking water have been also reported to account for BC development [11,12].

$\mathrm{BC}$ is a heterogeneous group of tumors with up to 40 histological subgroups. Fortunately, novel therapeutics are evolving for BC therapy beyond chemotherapy, which includes immunotherapy and molecular targeted agents. Most of BC cases are urothelial carcinomas, and $10 \%$ of them are non-urothelial carcinomas [3,13]. For each of the aforementioned types of BC, there are different subtypes. For instance, urothelial carcinomas are divided into different subtypes based on histopathological profile such as conventional urothelial carcinoma, variant urothelial carcinoma and so on. The advantageous of this subtyping is of importance for precision therapy, and providing effective and separate diagnosis and treatment [14].

Although different subtypes have been developed for BC and much effort has been conducted for using chemotherapy and radiotherapy in BC therapy, the cure of BC patients remains one of the big challenges for scientists. Partly, this difficulty in treating BC is due to poor understanding of molecular profile of BC. In spite of experiments for revealing genetic factors and molecular pathways involved in $\mathrm{BC}$ progression and malignancy, there is still a long way, since cancer cells use dynamic and flexible molecular pathways for ensuring their proliferation and invasion. A group of these molecular signaling pathways involved in proliferation and migration of BC cells, and enhance their viability known as oncogenic pathways such as Wnt [15], STAT3 [16], Nrf2 [17], PI3K/Akt [18], ZEB [19], and oncogenic microRNAs (miRNAs) and long non-coding RNAs (lncRNAs) [20,21]. Another group of molecular pathways include those which inhibit growth and metastasis of BC cells such as PTEN [22], AMPK [23], and onco-suppressor miRNAs and lncRNAs [24,25]. These molecular pathways have been extensively studied in BC cells and there are excellent reviews about them.

One of the issues in treatment of patients with BC is the high metastatic capability of BC cells that negatively affects overall survival of patients with this life-threatening disorder, and remarkably reduces efficacy of chemotherapy and radiotherapy, since cancer cells migrate in neighboring and distant tissues, providing problems with their effective eradication [26-28]. Several molecular pathways such as ZEB1 [19], EZH2 [29], PI3K/Akt [30], and so on have been identified as potential factors involved 
in metastasis and invasion of BC cells. Epithelial-to-mesenchymal transition (EMT) is one of the most important molecular pathways that enhanced migratory ability of cancer cells [31,32]. Interestingly, EMT has been recognized as a potential downstream target of miRNAs in cancer cells [33-37]. In the present review, we focus on metastatic BC cells, and the role of miRNA/EMT axis. This review will provide a comprehensive discussion about the role of miRNA/EMT in malignant behavior and strategies to target this axis in BC cells.

\section{EMT Mechanism}

The first definition of EMT is transformation of epithelial cells into mesenchymal ones that have migratory features and can be accompanied by downregulation of epithelial markers such as E-cadherin, and upregulation of mesenchymal markers such as $\mathrm{N}$-cadherin and vimentin [38,39]. Epithelial cells have cell-cell junctions, apico-basal polarity and low potential in migration. The epithelial cells are detected via their cell surface markers including E cadherin (as the most important and well-known factor), cytokeratins, occluding and claudins [40-43]. However, these properties are reversed in mesenchymal cells during EMT. Mesenchymal cells have front-rear polarity and potential in migration. There are surface markers by which mesenchymal cells are recognized, including N-cadherin, fibronectin and vimentin [44-48]. The EMT process was first observed during embryonic development. It was found that EMT is a vital mechanism for mesoderm formation and neural crest delamination. Based on dynamic property of cell identity, different mechanisms may be involved in ensuring this feature and EMT is one of them. During EMT activation, cells lose their identity and morphology to become a new one with mesenchymal characteristics $[49,50]$. It is worth mentioning that EMT is a reversible mechanism and its converse route is known as mesenchymal-to-epithelial transition (MET) [51].

A variety of transcriptional and epigenetic factors can contribute to regulation of EMT and MET. Although EMT is vital for physiological conditions such as organismal development, tissue healing and homeostasis, cancer cells hijack EMT to ensure their migration [52-56]. In order to occupy and colonize in distant tissues, cancer cells use EMT mechanism to promote their migratory ability [57-60]. It has been noted that EMT mechanism not only ensures invasion of cancer cells, but also is involved in reducing sensitivity of cancer cells into apoptosis and stimulation of chemoresistance [61,62]. EMT is not a binary state procedure and has a dynamic spectrum in which cells can have both epithelial and mesenchymal features [63-68]. Moreover, the cells undergoing EMT have more tumor-initiating potential and are resistant to apoptosis $[69,70]$. Furthermore, cancer cells are required to alter their metabolism in order to meet their energy needs and synthesize biomolecules such as proteins, lipids, and nucleic acids [71,72]. The most important change in metabolism of cancer cells is shifting from oxidative phosphorylation into glycolysis to meet their needs into adenosine triphosphate (ATP). This is known as Warbrug effect [73]. There is a close relationship between EMT and glucose metabolism in which glycolysis, tricarboxylic acid cycle (TCA) cycle, lipid and amino acid metabolism participate in EMT induction and stimulating invasion and migration of cancer cells [74,75].

A number of published articles have investigated the role of molecular pathways in regulation of EMT in cancer cells [41,76]. Due to space limitations, it is impossible to discuss all the molecular pathways involved in EMT regulation in cancer cells. However, we briefly discuss upstream mediators of EMT in cancer cells. Increasing evidence demonstrates that tumorigenesis and EMT can be regulated by transcription factor STAT3 in cancer cells $[77,78]$. In a recently published article, it was found that phosphorylation of STAT3 at tyrosine ${ }^{705}$ is associated with an increase in metastasis and migration of cancer cells via EMT induction. Moreover, STAT3-mediated EMT stimulation mediates resistance of cancer cells into cisplatin chemotherapy [79]. In fact, relationship between STAT3 and EMT not only is beneficial for invasion of cancer cells, but can also trigger chemoresistance. In addition to STAT3, other molecular factors have been identified as regulators of EMT. It has been reported that non-muscle myosin IIA (NMIIA) can participate in regulation of EMT in cancer cells. NMIIA can play an important role in controlling cell cytokinesis and migration. NMIIA triggers Wnt/ $\beta$-catenin signaling pathway, which in turn, stimulates EMT, leading to enhance metastasis and invasion of cancer cells [80]. 
EMT induction is mediated via upregulation of N-cadherin and downregulation of E-cadherin [81]. LncRNAs are also able to regulate EMT in cancer cells. LncRNA FLVCR1-AS1 can also elevate migration and metastasis of ovarian cancer cells via EMT induction [82]. These studies are in agreement with the fact that different molecular pathways contribute to EMT regulation. These pathways have been examined in different cancers and their further targeting can pave the way for effective suppression of cancer metastasis [83-86].

\section{MicroRNAs and Their Role in Cancer Metastasis}

MiRs are single stranded non-coding RNAs with a length of 19-24 nucleotides [86,87]. They can negatively affect expression of target gene via binding into 3/-untranslated region (3/-UTR) [88]. MiRs have been reported to be involved in regulation of various biological mechanisms such as differentiation, apoptosis, angiogenesis, proliferation, etc. and an impairment in their expression can provide conditions for development of diverse malignancies [89-93]. Accumulating data demonstrates that miRs are potential upstream regulators of EMT in cancer cells. The modulatory effect of miRs on EMT can regulate the processes of metastasis and invasion of cancer cells. For example, MiR-451a is considered an onco-suppressor $\mathrm{miR}$ in hepatocellular carcinoma cells. This miR is able to suppress metastasis of hepatocellular carcinoma cells, and thereby interfere with migration of cancer cells by promoting inhibition of EMT [33]. Transforming growth factor-beta (TGF- $\beta$ ) is involved in cancer progression via EMT induction [94]. TGF- $\beta$-mediated EMT can also be targeted by miRs. It has been reported that miR-455-3p can restrict migration of cancer cells via down-regulation of TGF- $\beta$, and subsequent inhibition of EMT [95]. In addition to onco-suppressor miRs, there are miRs that can significantly increase migratory capability of cancer cells such as miR-HCC2. It has been reported that miR-HCC2 can increase the migration and metastasis of cancer cells via EMT induction [96]. In EMT induction, oncogene miRs may also affect upstream mediators of EMT. For instance, it has been documented that miR-499a-5p facilitates metastasis of lung cancer cells via upregulation of mammalian target of rapamycin (mTOR), and subsequent stimulation of EMT [35].

\section{MicroRNAs Inhibit EMT in Bladder Cancer Cells}

In the previous sections, we described EMT mechanism and its regulation by different molecular pathways with an emphasis on miRNAs. In this section, we specifically discuss the role of onco-suppressor miRNAs in inhibition of EMT in BC cells. Interestingly, expression analysis has revealed that onco-suppressor miRNAs undergo downregulation in BC cells and tissues. This occurs to ensure proliferation and migration of $\mathrm{BC}$ cells and is correlated with poor prognosis of patients with BC. miRNA-124-3p is an onco-suppressor miRNA and it appears that enhancing expression of this miRNA can disrupt migration of BC cells. In addition, miRNA-124-3p can inhibit EMT via E-cadherin upregulation and N-cadherin downregulation. Moreover, EMT inhibition by miRNA-124-3p relies on affecting integrin $\alpha 3$ (ITGA3). Increasing evidence demonstrates that ITGA3 is able to promote migration of cancer cells, and it is a downstream target of miRNAs [97,98]. In case of BC, miRNA-124-3p can target ITGA3 to suppress EMT, leading to a decrease in migration of BC cells [89]. Another study also emphasized the role of ITGA3 in metastasis of BC cells, and inhibitory effect of miRNA-328-3p on ITGA2 in suppressing BC migration [99].

\subsection{MicroRNAs and PI3K/Akt/EMT Axis}

PI3K/Akt signaling pathway can act as an inducer of metastasis in several malignancies including BC cells [100-102]. Anti-tumor agents such as leupaxin can suppress invasion of BC cells via PI3K/Akt downregulation [103]. miRNA-328-3p is considered as an onco-suppressor factor in BC cells. It has been found that miRNA-328-3p inhibits EMT via PI3K/Akt downregulation [99]. miRNAs are also able to affect downstream targets of PI3K/Akt signaling pathway in BC cells. B cell-specific Moloney murine leukemia virus integration site 1 (BMI1) is suggested to undergo upregulation in different cancers. BMI1 overexpression ensures tumor sphere formation of cancer cells, and its stability is a 
positive factor for tumorigenesis [104,105]. MiR-15 as an onco-suppressor factor has been reported to inhibit EMT in BC cells. It appears that miRNA-15 inhibits PI3K/Akt signaling pathway to suppress BMI1 expression, leading to EMT inhibition and decreased invasion of BC cells [106].

\subsection{MicroRNAs and CARMA3/EMT Axis}

An extensive amount of research has focused on various factors involved in metastasis of BC cells and a considerable role of EMT in malignant behavior and metastasis of these malignant cells has been established [107,108]. Interestingly, CARD-containing MAGUK 3 (CARMA3) is a scaffold with capability of stimulation of nuclear factor-kappa B (NF- $\mathrm{B}$ ) signaling pathway and enhancing tumor growth [109-112]. downregulation of CARMA3 is of interest in suppressing metastasis of BC cells, since CARMA3 is able to induce matrix metalloproteinase-2 (MMP-2), MMP-9 and c-Myc expression that are involved in the migration of BC cells. Besides, CARMA3 can reduce the levels of E-cadherin, whereas it increases $\beta$-catenin levels [113]. Moreover, miRNA-24 has gained much attention as a therapeutic target in BC therapy and it has been noted that that miRNA-24 can down-regulates the expression of CARMA3 to suppress EMT via increasing E-cadherin levels, and decreasing N-cadherin, vimentin and MMP-9 levels [114].

\subsection{MicroRNAs and Wnt/EMT Axis}

The Wnt/ $\beta$-catenin signaling pathway has been under attention in recent years due to its role in tumorigenesis [115-119]. The tumor-promoting role of Wnt signaling pathway has been investigated in different cancers, including BC [120,121]. It has been found that Wnt signaling can act as an upstream mediator of EMT, so that after activation of Wnt signaling pathway by certain ligands of Wnt family, GSK-3 $\beta$ activity can be inhibited to facilitate the nuclear translocation of $\beta$-catenin. Thereafter, various downstream targets with stimulatory effect on proliferation and migration of cancer cells are activated [122-125]. EMT is a downstream effectt of Wnt activation in cancer progression [86,126]. miRNAs are able to regulate Wnt/EMT axis in BC cells. miRNA-3619-5p as an onco-suppressor factor in BC cells, is able to inhibit metastasis of BC cells. Moreover, examination of molecular pathways shows that miRNA-3619-5p can inhibit Wnt signaling pathway via suppressing nuclear translocation of $\beta$-catenin. As a consequence, a decrease occurs in EMT and mesenchymal markers causing an inhibition in invasion of BC cells [127]. Moreover, it has been demonstrated that Wnt7a is capable of induction of Wnt signaling pathway that in turn, enhances $\beta$-catenin levels to stimulate EMT, leading to increased migration and invasion of BC cells. miRNA-370-3p can suppress Wnt-mediated EMT via inhibition of EMT [115], thus making it an important therapeutic target for BC therapy.

\subsection{MicroRNAs and EMT-Inducing Transcription Factors}

TGF- $\beta$ is another signaling pathway that plays a vital role in cancer malignancy [128]. Briefly, TGF- $\beta$ induces the formation of Smad complex that can translocate into the nucleus and affect target genes $[129,130]$. TGF- $\beta$ can promote migration and metastasis of cancer cells via EMT induction [131,132]. In BC cells, TGF- $\beta 1$ induces nuclear translocation of Smad2, which in turn, stimulates EMT and can enhance BC migration. miRNA-132 inhibits TGF- $\beta 1 / S m a d 2 / E M T$ axis in suppressing BC invasion [133]. In addition to TGF- $\beta$, ZEB1 can also induce EMT. Both TGF- $\beta$ and ZEB1 belong to EMT-inducing transcription factors (EMT-TFs). Similar to TGF- $\beta$, ZEB1 is able to stimulate EMT in promoting invasion and metastasis of cancer cells [134,135]. In BC cells, miRNAs are able to affect ZEB1 expression. For instance, miRNA-23b interferes with migration of BC cells into distant tissues by EMT inhibition via downregulation of ZEB1 [136]. Twist1 is another member of EMT-TFs. Twist1 is an enhancer of EMT in cancer cells and has been linked with invasion and migration [137,138]. miRNA-203 has demonstrated onco-suppressor role in BC cells by causing a downregulation of Twist1. Decreased expression of Twist1 is associated with a diminution in EMT and limited migration of BC cells [139]. Slug can also be affected by miRNAs in BC cells, which is able to induce EMT, and its activity can be regulated by MAPK $[140,141]$. MAPK/Slug/EMT axis is of importance in BC cells, and miRNAs 
have demonstrated great potential in its regulation. On the contrary, miRNA-22 as an onco-suppressor is able to inhibit MAPK signaling pathway [142,143]. A recently published study has examined the effect of miRNA-22 on MAPK/Slug/EMT axis in BC cells. It was found that miRNA-22 can bind to 3/UTR of MAPK to inhibit its activity. Consequently, MAPK-induced Slug expression can be reduced and a decrease occurs in the levels of vimentin, as a marker of mesenchymal cells. These effects result in inhibition of EMT in BC cells. Furthermore, miRNA-22 can suppress Snail in causing EMT inhibition in BC cells [144]. These studies are in agreement with the fact that miRNAs are able to target EMT-TFs in suppressing metastasis of BC cells. In addition, because of substantial capability of miRNAs in forming feedback loops among divesre oncogenic molecular pathways, it appears that anti-tumor agents or genetic tools applied for targeting aforementioned signaling pathways may not be effective enough to overcome cancer metastasis and EMT [145-148]. In fact, eradication of BC cells, and suppressing their migration may depend on using a combination of anti-tumor agents (poly-chemotherapy) capable of targeting various molecular pathways or using genetic tools for silencing various downstream targets of miRNAs that are involved in regulating EMT (Table 1, Figure 1).

Table 1. MicroRNAs inhibit EMT in BC cells.

\begin{tabular}{|c|c|c|c|c|}
\hline MicroRNA & $\begin{array}{l}\text { Downstream } \\
\text { Target }\end{array}$ & Cell Line & Major Outcomes & Refs \\
\hline miRNA-370 & SOX12 & $\begin{array}{l}\text { Immortalized bladder cell line } \\
\text { SV-HUC-1 (ATCC }{ }^{\circledR} \\
\text { CRL-9520 } \\
\text { cell lines } 5637 \text { (ATCC }{ }^{\circledR} \text { HTB-9T the human BC } \\
\text { and J82 (ATCC }{ }^{\circledR} \text { HTB-1 }^{\mathrm{TM}} \text { ) }\end{array}$ & $\begin{array}{l}\text { miRNA-370 inhibits EMT via SOX12 } \\
\text { downregulation, leading to a } \\
\text { decreased metastasis of cancer cells }\end{array}$ & [149] \\
\hline miRNA-34a & CD44 & $\begin{array}{c}\text { Human bladder cancer cell lines } \\
(5637, \text { T24, HT-1376, J82, } \\
\text { SCABER and EJ) }\end{array}$ & Suppressing EMT via CD44 inhibition & {$[150]$} \\
\hline miRNA-613 & SphK1 & $\begin{array}{c}\text { Bladder cancer cell lines (J82, } \\
\text { T24, UMUC3 and 5637) and a } \\
\text { normal bladder cell } \\
\text { line (SV-HUC-1) }\end{array}$ & $\begin{array}{l}\text { Inhibition of SphK1 and reduced } \\
\text { metastasis and EMT }\end{array}$ & {$[151]$} \\
\hline miRNA-186 & NSBP1 & $\begin{array}{c}\text { Human bladder cancer cell lines } \\
\text { (J82, HT1376, RT4, T24 and } \\
\text { TCCSUP) and immortalized } \\
\text { human bladder epithelium } \\
\text { (HCV29) cells }\end{array}$ & $\begin{array}{c}\text { downregulation of NSBP1 and } \\
\text { suppressed metastasis of cancer cells }\end{array}$ & {$[152]$} \\
\hline miRNA-125a-5p & FUT4 & $\begin{array}{c}\text { Bladder cancer cell lines (J82, } \\
\text { T24, } 5637 \text { and BIU-87) and } \\
\text { im-mortalized bladder cell } \\
\text { line (SV-HUC-1) }\end{array}$ & $\begin{array}{c}\text { miRNA-125a-5p inhibits invasion and } \\
\text { EMT in BC cells via FUT4 } \\
\text { downregulation }\end{array}$ & {$[153]$} \\
\hline miRNA-203a & SIX4 & $\begin{array}{l}\text { SV-HUC-1 human uro-epithelial } \\
\text { cells and the bladder cancer cell } \\
\text { lines T24, EJ, J8 and } 5637\end{array}$ & $\begin{array}{c}\text { There is a negative relationship } \\
\text { between miRNA-203a and SIX4. } \\
\text { This miRNA inhibits EMT via } \\
\text { SIX4 downregulation }\end{array}$ & [154] \\
\hline miRNA-22 & $\mathrm{E} 2 \mathrm{~F} 3$ & $\begin{array}{c}\text { Human bladder cancer cell lines } \\
\text { (5637 and T24) }\end{array}$ & $\begin{array}{l}\text { Preventing expression of E2F3 and } \\
\text { suppressed BC metastasis and EMT }\end{array}$ & {$[155]$} \\
\hline $\begin{array}{l}\text { miRNA-454-3p } \\
\text { miRNA-374b-5p }\end{array}$ & ZEB2 & $\begin{array}{l}\text { SV-HUC, TCC, 253J, 5637, J82, } \\
\text { T24, EJ, HEK-293T cells }\end{array}$ & $\begin{array}{c}\text { Suppressing EMT via ZEB2 } \\
\text { downregulation }\end{array}$ & {$[156]$} \\
\hline miRNA-451 & - & $\begin{array}{c}\text { T24, } 5637 \text { and J28 bladder cancer } \\
\text { cell lines }\end{array}$ & $\begin{array}{c}\text { Inhibiting EMT via E-cadherin } \\
\text { upregulation, and N-cadherin and } \\
\text { vimentin downregulation }\end{array}$ & [157] \\
\hline miRNA-199a-5p & CCR7 & $\begin{array}{l}\text { Human bladder cancer T24 cell } \\
\text { line and human normal bladder } \\
\text { epithelial cell line SV-HUC-1 }\end{array}$ & $\begin{array}{l}\text { Interfering with metastasis of cancer } \\
\text { cells by downregulation of CCR7, } \\
\text { and subsequent inhibition of EMT }\end{array}$ & {$[158]$} \\
\hline miRNA-7-5p & Gli3 & $\begin{array}{c}\text { TCC, 253J, 5637, T24, EJ, } \\
\text { J82 (BCa cell lines) and SV-HUC } \\
\text { (human bladder epithelium } \\
\text { immortalized cell) }\end{array}$ & $\begin{array}{l}\text { miRNA-7-5p reduces expression of } \\
\text { Gli3 as a member of Hedgehog } \\
\text { signaling pathway to suppress EMT }\end{array}$ & [159] \\
\hline miRNA-200 & - & $\begin{array}{l}\text { UMUC series of urothelial } \\
\text { carcinomas and 253J BV cells }\end{array}$ & $\begin{array}{l}\text { miRNA-200 enhances E-cadherin } \\
\text { levels, and reduces ZEB1 and ZEB2 } \\
\text { levels to inhibit EMT, leading to a } \\
\text { diminution in metastasis and } \\
\text { enhanced sensitivity } \\
\text { into chemotherapy }\end{array}$ & {$[160]$} \\
\hline
\end{tabular}


Table 1. Cont.

\begin{tabular}{|c|c|c|c|c|}
\hline MicroRNA & $\begin{array}{l}\text { Downstream } \\
\text { Target }\end{array}$ & Cell Line & Major Outcomes & Refs \\
\hline miRNA-200c & $\begin{array}{l}\text { BMI1 } \\
\text { E2F3 }\end{array}$ & $\begin{array}{l}\text { Human bladder cancer cell lines } \\
\text { (UMUC-3 and T24) }\end{array}$ & $\begin{array}{l}\text { Suppressing EMT and increasing } \\
\text { E-cadherin levels via inhibition of } \\
\text { BMI1 and E2F3 }\end{array}$ & [161] \\
\hline miRNA-485-5p & HMGA2 & $\begin{array}{l}\text { Human bladder cancer cell lines } \\
\text { (SW780, T24, HT1376 and } \\
\text { HT5637) and human bladder } \\
\text { epithelial cell lines HU609 and } \\
\text { HEK293 cell }\end{array}$ & $\begin{array}{c}\text { Disrupting invasion of cancer cells by } \\
\text { EMT inhibition via } \\
\text { HMGA2 downregulation }\end{array}$ & [162] \\
\hline miRNA-429 & $\begin{array}{c}\text { ZEB1/2 } \\
\beta \text {-catenin }\end{array}$ & Human UCC cell lines, T24 & $\begin{array}{l}\text { Enhancing E-cadherin level via } \\
\text { ZEB1/2 downregulation and } \\
\text { subsequent inhibition of EMT } \\
\text { Suppressing nuclear translocation of } \\
\beta \text {-catenin and its interaction with } \\
\text { TCF/LEF1 resulting in EMT inhibition }\end{array}$ & [163] \\
\hline miRNA-381-3p & CCNA2 & $\begin{array}{l}\text { T24, UM-UC3, and } 5637 \text { human } \\
\text { BCa cell lines }\end{array}$ & $\begin{array}{l}\text { Inhibition of EMT via } \\
\text { CCNA2 downregulation }\end{array}$ & [164] \\
\hline
\end{tabular}

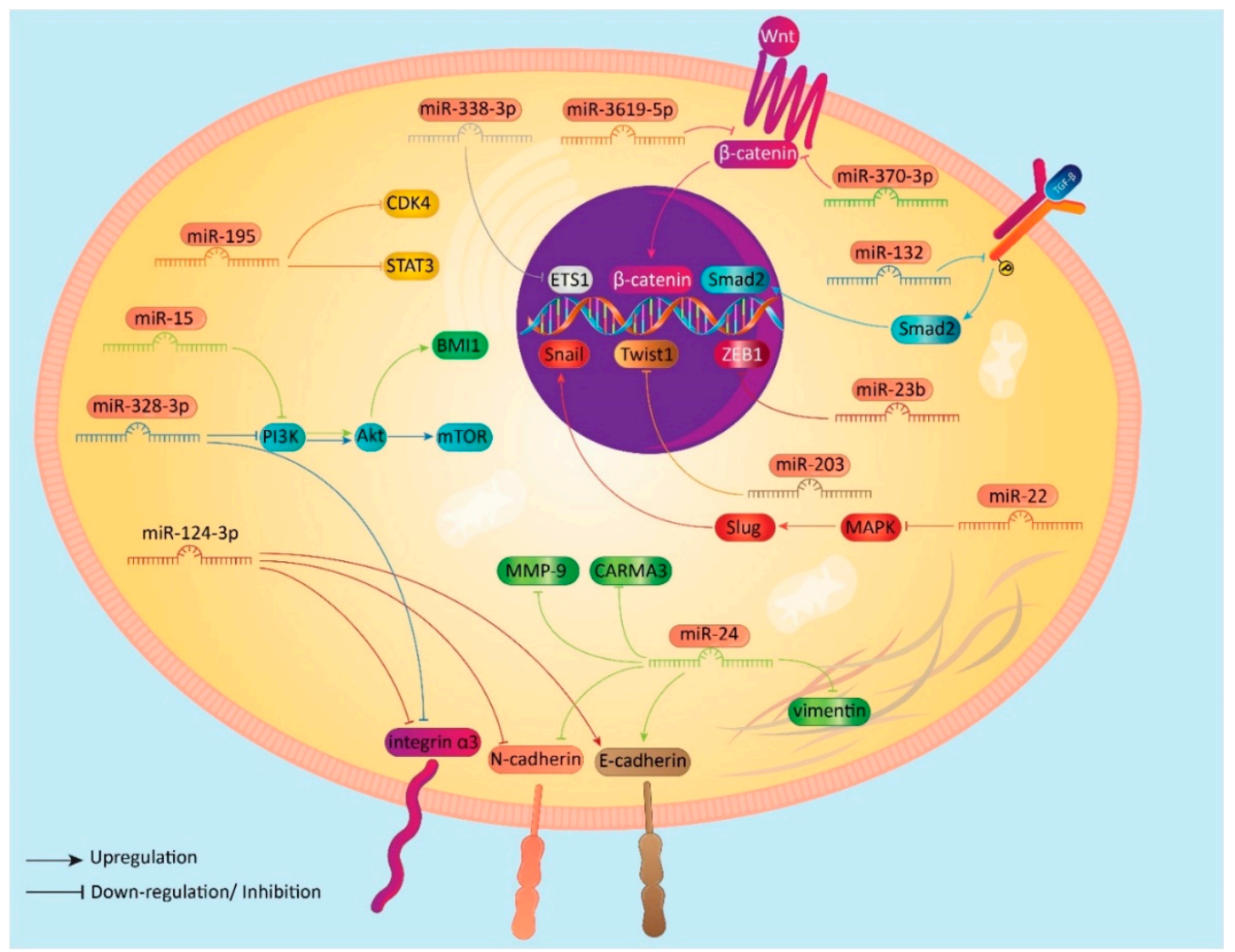

Figure 1. Inhibition of EMT in BC cells by miRNAs.

\section{5. miRNA-200 Family and EMT}

A well-known family of miRNAs that are capable of EMT regulation in different cancers is miRNA-200 family $[165,166]$. The EMT inhibition by miRNA-200 is a gateway for enhancing efficacy of chemotherapy [167]. ZEB proteins that can act as critical enhancers of EMT are often downregulated by miRNA-200 to suppress cancer migration (EMT) [168]. Noteworthy, two studies have evaluated role of miRNA-200 in affecting BC metastasis via EMT regulation. These studies are in accordance with our aforementioned discussions and show that EMT regulation by miRNA-200 leads to enhanced efficacy of chemotherapy and migration inhibition. EMT induction by ZEB proteins (ZEB1 and ZEB2) is a factor involved in resistance of BC cells into chemotherapy. Stable expression of miRNA-200 leads to inhibition of ZEB1 and ZEB2 that can lead to an increased levels of E-cadherin, thus causing a 
reduced migratory ability of $\mathrm{BC}$ cells [160]. This study highlights the fact that cancer may acquire chemoresistance, when they demonstrate malignant behaviors such as invasion. Therefore, EMT acts as a critical factor in cancer metastasis, and signaling pathways regulating this mechanism need to be identified in detail, and miRNAs are possibly one of them. Another study investigated the relationship between miRNA-200 and EMT in BC migration, while previous study demonstrated involvement of miRNA-200/EMT axis in BC chemoresistance. It has been reported that miRNA-200 can reduce expression of BMI and E2F3 as inducers of BC metastasis that results in EMT inhibition via E-cadherin upregulation [161]. Further studies can focus on identifying more downstream targets of miRNA-200 and how they can regulate both EMT and metastasis of BC cells.

\subsection{Other microRNAs}

In addition, clinical studies have shown that miRNA-195 undergoes downregulation in patients with BC, and is associated with undesirable prognosis [169]. This miRNA is able to suppress proliferation and progression of BC cells via STAT3 inhibition [170]. Moreover, a downregulation of miRNA-195 by lncRNA UCA1 can promote mitochondrial function and growth of BC cells [171]. miRNA-195 is also able to inhibit EMT in BC cells via CDK4 inhibition [172]. In addition, studies have demonstrated that different molecular pathways ensure progression and migration of $\mathrm{BC}$ cells. For example, E26 transformation specific-1 (ETS1) is an oncogene factor in BC cells, and its induction can elevate migration of BC cells $[173,174]$. There is a negative relationship between miRNA-338-3p and ETS1 in BC cells. Moreover, by causing a downregulation of ETS1, miRNA-338-3p can abrogate EMT in BC cells to suppress migration of BC cells [175].

\section{MicroRNAs can Induce EMT in BC Cells}

\subsection{MicroRNAs and Wnt/EMT Axis}

In previous section, we have highlighted that Wnt signaling pathway contributes to stimulation of EMT via $\beta$-catenin's nuclear translocation. It was revealed that miRNA-3619-5p acts as an onco-suppressor, targets nuclear translocation of $\beta$-catenin. However, it has been reported that miRNAs can also target GSK-3 $\beta$ activity. miRNA-135a has demonstrated an oncogene role in BC cells. It appears that miRNA-135a induces EMT mechanism to promote metastasis of BC cells. Investigation of molecular pathways showed that miRNA-135a can induce Wnt/ $\beta$-catenin signaling pathway via inhibiting GSK-3 $\beta$ activity. Therefater, $\beta$-catenin undergoes nuclear translocation that activates EMT, leading to enhanced migratory ability of BC cells [176]. miRNA-135a/Wnt/EMT can therefore be targeted in further studies to inhibit the migration of $\mathrm{BC}$ cells.

\subsection{MicroRNAs and EMT-Inducing Transcription Factors}

Although onco-suppressor miRNAs reduce expression of EMT-TFs to suppress EMT in BC cells, there are oncogenic miRNAs capable of enhancing expression of EMT-TFs in EMT induction. TGF- $\beta 1$ is able to induce EMT in BC cells and miRNA-96 as an oncogene factor upregulating the expression of TGF- $\beta 1$ to stimulate EMT in BC cells and thus promoting their migration and invasion [177]. Stathmin 1 (STMN1) is a microtubule-destabilizing protein that plays a vital role in mitosis and cell cycle progression [178,179]. STMN1 is considered as an oncogenic protein, its induction enhances invasion and metastasis of cancer cells $[180,181]$. It has been reported that miRNA-221 can induce EMT in BC cells via induction of TGF- $\beta$. The stimulatory effect of miRNA-221 on TGF- $\beta$-mediated EMT relies primarily on inhibition of STMN1 [182].

\subsection{MicroRNAs and EGR1/EMT Axis}

In addition, early growth response gene 1 (EGR1) acts as a double-edged sword in cancer by displaying both tumor promoting and suppressing roles. EGR1 can reduce apoptosis of cancer cells and promote their migration and angiogenesis $[183,184]$. However, there are studies showing anti-tumor 
activity of EGR1 and its role in suppressing metastasis of cancer cells [185]. Moreover, miRNA-301b and EGR1 can act in conjunction to regulate EMT in BC cells. It was found that miRNA-301b has high expression in BC cells, while EGR1 undergoes downregulation in these malignant cells. Investigation of molecular pathways revealed that miRNA-301b can induce EMT in BC cells via EGR1 downregulation [186].

\subsection{Other microRNAs}

The difficulty in inhibiting metastasis of BC cells is due to involvement of different and complicated molecular pathways in progression of BC cells. RhoB is key member of Rho family and a GTP-binding protein. Increasing evidence demonstrates that RhoB undergoes downregulation in cancer cells and is correlated with poor prognosis $[187,188]$. RhoB has also been found to inhibit metastasis via EMT downregulation [189]. Based on inhibitory effect of RhoB on EMT, its activity and expression should be diminished by oncogenic miRNAs. Indeed, it was reported that miRNA-19a can promote metastasis and invasion of BC cells by EMT induction via reducing RhoB levels [190].

DAB2IP is a member of RAS-GTPase-activating protein family and its expression has been found to be downregulated in cancer cells [191]. It has been shown that inhibition of DAB2IP in BC cells can mediate both chemoresistance and metastasis $[192,193]$. Therefore, targeting DAB2IP is of interest for minimizing the migration of $B C$ cells. In order to ensure invasion of $B C$ cells, miRNA-92b can affects DAB2IP effectively. In fact, by causing an inhibition of DAB2IP, miRNA-92b induces EMT, leading to enhanced migration and invasion of BC cells [194]. These studies clearly establish that miRNAs are able to induce EMT in BC cells. However, most of the studies have focused on onco-suppressor miRNAs, and their capability in inhibition of EMT in BC cells. In addition, other studies have also paid attention into regulation of miRNA/EMT axis by other important molecular signaling pathways. Hence, more studies are needed to identify oncogenic miRNAs, which can induce EMT in BC cells to target them effectively for suppressing migration and metastasis of BC cells (Figure 2).

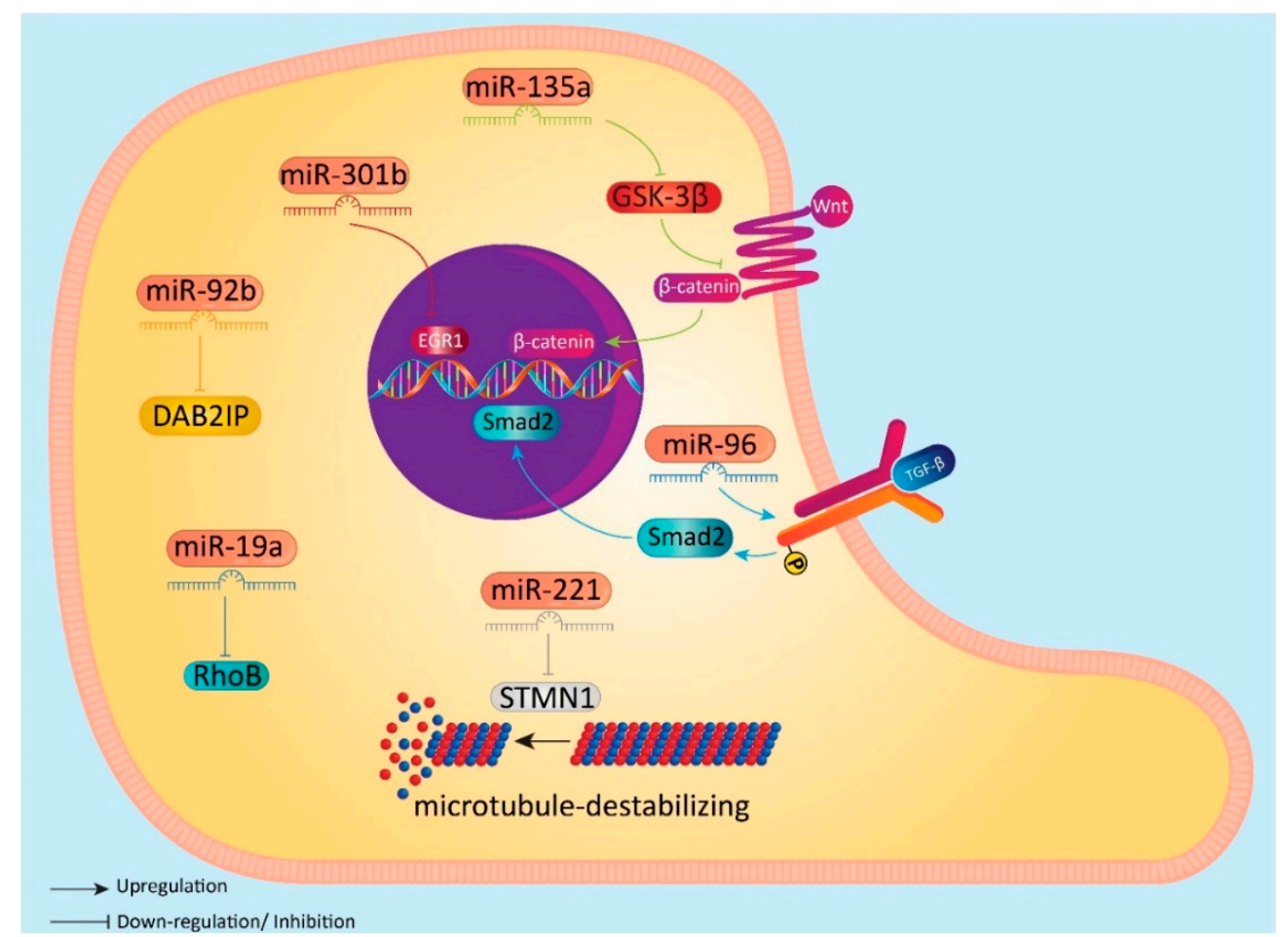

Figure 2. Induction of EMT by miRNAs in BC cells. 


\section{Regulation of mciroRNA/EMT in Bladder Cancer Cells}

\subsection{LncRNAs as Main Regulators}

Although miRNAs are potential upstream modulators of EMT in BC cells, and according to previously reported findings, they can target EMT via affecting different molecular pathways. In addition, there are studies showing that several important molecular pathways can also influence miRNAs. This demonstrates the complexity of molecular pathways involved in regulating EMT in BC cells. Similar to miRNAs, lncRNAs are key members of non-coding RNA family that can participate in regulation of vital biological mechanisms such as cell proliferation and cell differentiation [183,195]. A number of studies have shown a significant role of lncRNAs in cancer cells, both as an oncogene or onco-suppressor $[196,197]$. Both miRNAs and lncRNAs can control the regulation of protein-coding genes [198]. LncRNAs are able to suppress interaction of miRNAs with their target via acting as molecular decoys and sequestering miRNAs [199,200]. Notably, miRNAs are downstream targets of lncRNAs in BC cells [201,202]. This dual relationship can be studied to draw a unique axis and potential therapeutic targeting in future studies. miRNAs are capaable to affect EMT-TFs involved in regulation of EMT in BC cells. LncRNA SNHG6 is an oncogene factor that can promote proliferation of cancer cells, and its downregulation can restrict malignant behavior of cancer cells [138]. Accumulating data demonstrates that SNHG6 can induce EMT in cancer cells via targeting EMT-TFs such as TGF- $\beta$ and ZEB1 [203], making it an efficient target in suppressing metastasis of cancer cells.

For instance, SNHG6/miRNA-125b/EMT has been implicated in the migration of BC cells. It has been reported that SNHG6 can down-regulate the expression of miR-125b as an onco-suppressing factor. Therefore, an increase occurs in expression of Snail1/2 and ZEB1 to induce EMT, leading to an enhanced metastasis of BC cells [204]. LncRNA H19 is an enhancer of growth and migration in BC cells. Increasing evidence demonstrates that $\mathrm{H} 19$ is able to enhance metastasis of BC cells by reducing E-cadherin levels via EZH2 induction [205]. This inhibitory effect of lncRNA H19 on E-cadherin levels can provide condition for migration and invasion of BC cells and undesirable prognosis [206]. An experiment has examined the relationship between lncRNA H19 and miRNA-29b-3p in regulation of EMT in BC cells. This study found that LncRNA H19 can function as an inhibitor of miRNA-29b-3p by sponging. Consequently, an increase occurs in expression of DNMT3B, as a downstream target of miRNA-29b-3p. This provides condition for induction of EMT by H19/miRNA-29b-3p/DNMT3B axis. Inhibition of lncRNA H19 leads to inhibition of EMT and stimulation of MET to suppress metastasis of BC cells [207]. It is worth highlighting that lncRNAs may indirectly affect EMT and metastasis of BC cells. The final aim of targeting miRNAs by lncRNAs in BC cells is to modulate downstream targets of miRNAs and regulate EMT mechanism. For instance, lncRNA LINC00612 is able to induce PHF14 expression via miRNA-590 inhibition, leading to EMT induction and metastasis of BC cells [208]. These studies are in agreement with the fact that lncRNAs can substantially affect miRNA/EMT axis in BC cells. However, more studies are needed to examine the relationship between lncRNAs and miRNA/EMT in BC cells to unravel this intriguing association.

\subsection{CircRNAs as Main Regulators}

Circular RNAs (circRNAs) are another member of non-coding RNAs capable of regulating miRNAs in cancer cells $[190,209]$. CircRNAs can be divided into onco-suppressor and oncogenic in BC. They are able to target different molecular pathways in BC cells and miRNAs are their major downstream targets [210,211]. In BC cells, circRNA circPICALM functions as an onco-suppressor factor via causing downregulation of miRNA-1265. The expression of this circRNA undergoes downregulation in BC cells and tissues and has been correlated with poor prognosis. In addition, analysis of molecular pathways has demonstrated that circPICALM can reduce the expression of miRNA-1265. STEAP4, as a downstream target miRNA-1265 undergoes upregulation, which in turn, can inhibit phosphorylation of FAK at Y397, resulting in inhibition of EMT and metastasis of BC cells [212]. In addition to miRNA-1265, it appears that miRNA-221 may be affected by circRNAs in BC cells. For instance, miRNA-221 is an 
oncogene factor that can reduce the number of cancer cells undergoes apoptosis to ensure proliferation and survival of BC cells [213]. Besides, miRNA-221 has also demonstrated immunosuppressor activity and can facilitate immune evasion of BC cells [214]. So, targeting miRNA-221 is of importance in suppressing malignant behavior of BC cells. Another example is that of CircMTO1 that acts as an onco-suppressor to inhibit miRNA-221 in BC cells. It appears that inhibition of miRNA-221 by circMTO1 may be related to a decrease in migration of BC cells. This is due to inhibition of miRNA-221 and enhancement of E-cadherin/ $\mathrm{N}$-cadherin ratio, thereby leading to EMT and metastasis inhibition of BC cells [183]. It is also noteworthy that circRNAs are able to indirectly affect EMT-TFs in BC cells by targeting miRNAs. As it was mentioned earlier, TGF- $\beta$ can act as a promoter of EMT in cancer cells and suppressing TGF- $\beta$ ca be promising strategy in metastasis inhibition. Moreover, CircRIP2 can function as an oncogenic factor in BC cells that can trigger EMT to ensure metastasis and malignant behavior of tumor cells. Interestingly, investigation of molecular pathways indicated that circRIP2 could reduce the expression of miRNA-1305 that in turn, can inhibit TGF- $\beta 2$ and its downstream target, Smad3. This eventually can lead to inhibition of EMT and decreased invasion of BC cells [215].

\subsection{Anti-Tumor Compounds as Main Regulators}

It is worth highlighting that pharmacologically active anti-tumor drugs are also able to target miRNAs for cancer therapy. Sulforaphane is a plant-derived natural compound exclusively found in cruciferous vegetables [216]. It has demonstrated high anti-tumor activity by induction of apoptosis and regulation of miRNAs, that can sensitize cancer cells to chemotherapy [217]. In BC cells, administration of sulforaphane has been suggested to be an ideal candidate for suppressing invasion and migration of cancer cells. In order to inhibit EMT in BC cells, sulforaphane can effectively target miRNA-200c/ZEB1 axis. miRNA-200c is an onco-suppressor factor and its upregulation by sulforaphane can lead to an inhibition of ZEB1 expression. This in turn can effectively suppress EMT and metastasis of BC cells [218]. Chronic inflammation acts as a positive factor for growth and malignancy of cancers, including BC [219,220]. Tumor-associated macrophages (TAMs) are key members of tumor microenvironment and their abundancy has been correlated with metastasis of cancer cells, and unfavorable prognosis [221,222]. BAY11-7082 as an inhibitor of oncogenic NF- $\mathrm{KB}$ signaling pathway [223-226] is able to inhibit stimulatory action of TAMs on EMT in BC cells. Normally, TAMs upregulate expression of miRNA-30a to induce NF- $\mathrm{B} /$ Snail signaling pathway, leading to EMT and invasion of BC cells. BAY11-7082 can decrease expression of miRNA-30a to disrupt NF- $\beta B / S n a i l$ axis, thereby restricting invasion of BC cells via inhibition of EMT [227]. Sodium butyrate (NaB) is a histone deacetylase inhibitor that is extensively applied in cancer therapy for inhibition of migration and induction of apoptosis via mitochondrial dysfunction [228-231]. Interestingly, administration of $\mathrm{NaB}$ has been found to be important in suppressing EMT in BC cells. It appears that NaB can enhance expression of miRNA-139-5p that in turn may reduce Bmi1 expression. Thus, miRNA-139-5p/Bmi1 axis cans lead to an increase in E-cadherin levels and a decrease in Snail, $\mathrm{N}$-cadherin and vimentin levels to inhibit EMT in BC cells [232]. Celecoxib is another anti-tumor agent capable of suppressing cancer proliferation via induction of oxidative stress [233]. Celecoxib is able to suppress metastasis of cancer cells via EMT inhibition [234]. A recent study has shown that celecoxib is able to target miRNAs in regulation of EMT in BC cells. Administration of celecoxib enhanced the expression of miRNA-145 that in turn, inhibited TGF $\beta$ R2. This leads to an inhibition of Smad3 and a decrease in migration and metastasis of BC cells via suppressing EMT [235]. These studies are in agreement with the fact that anti-tumor compounds can affect miRNAs in regulation of EMT in BC cells and more studies will be needed to discover novel anti-tumor drugs with modulatory impact on miRNA/EMT axis in BC cells. To date, a variety of studies have examined regulation of miRNA/EMT axis in BC cells. LncRNAs are major upstream regulators of miRNA/EMT axis in BC cells and experiments have extensively investigated their relationship with metastasis of BC cells. The p53 and KCNQ1OT1 are other upstream mediators capable of regulating miRNA/EMT axis in BC cells [236,237]. Overall, identification of these 
signaling pathways will enable us to target them in further studies and effectively inhibit metastasis of BC cells (Table 2, Figure 3).

Table 2. Regulation of microRNA/EMT axis in BC cells.

\begin{tabular}{|c|c|c|c|c|c|}
\hline $\begin{array}{l}\text { Upstream } \\
\text { Regulator }\end{array}$ & MicroRNA & $\begin{array}{l}\text { Downstream } \\
\text { Target }\end{array}$ & Cell Line & Major Outcomes & Refs \\
\hline $\begin{array}{l}\text { LncRNA } \\
\text { DANCR }\end{array}$ & miRNA-149 & MSI2 & $\begin{array}{c}\text { Bladder cancer 5637, } \\
\text { SW780, UM-UC-3, } \\
\text { T24 and SV-HUC-1 cells }\end{array}$ & $\begin{array}{l}\text { DANCR enhanced metastasis and } \\
\text { invasion of cancer cells by } \\
\text { downregulation of miRNA-149, } \\
\text { and subsequent activation of } \\
\text { MSI2, resulting in EMT }\end{array}$ & [238] \\
\hline LncRNA ARSR & miRNA-129-5p & SOX4 & RT4 and 5637 cells & $\begin{array}{l}\text { ARSR reduces expression of } \\
\text { miRNA-129-5p via sponging to } \\
\text { upregulate SOX4, leading to EMT }\end{array}$ & [239] \\
\hline LncRNA XIST & miRNA-200c & - & $\begin{array}{l}\text { Human bladder cancer } \\
\text { cell lines } 5637 \text { and T24 }\end{array}$ & $\begin{array}{l}\text { Stimulation of EMT by } \\
\text { downregulation of miRNA-200c }\end{array}$ & [240] \\
\hline LncRNA UCA1 & miRNA-143 & HMGB1 & $\begin{array}{l}\text { Human bladder cancer } \\
\text { cell lines (T24, 5637, J82, } \\
\text { RT4 and HT1376) }\end{array}$ & $\begin{array}{l}\text { UCA1 induces expression of } \\
\text { HMGB1 via miRNA-143 } \\
\text { downregulation, leading to EMT }\end{array}$ & [241] \\
\hline LncRNA UCA1 & miRNA-145 & ZEB1/2 & $\begin{array}{c}\text { Human bladder cancer } \\
\text { cells } 5637, \mathrm{~T} 24 \\
\text { and UMUC2 }\end{array}$ & $\begin{array}{c}\text { Stimulation of EMT by } \\
\text { downregulation of miRNA-145 } \\
\text { and subsequent activation } \\
\text { of ZEB1/2 }\end{array}$ & [242] \\
\hline $\begin{array}{c}\text { LncRNA } \\
\text { AC114812.8 }\end{array}$ & miRNA-371b-5p & FUT4 & $\begin{array}{l}\text { Human BC cell lines T24, } \\
\text { UM-UC-3, J82, and 5637, } \\
\text { and the human } \\
\text { immortalized normal } \\
\text { urinary epithelial cell } \\
\text { line SV-HUC-1 }\end{array}$ & $\begin{array}{c}\text { Sponging of miiR-371b-5p by } \\
\text { AC114812.8 leads to induction of } \\
\text { FUT4, and EMT }\end{array}$ & [243] \\
\hline LncRNA TUG1 & miRNA-145 & - & SV-HUC-1 cells & $\begin{array}{c}\text { TUG1 induces EMT via } \\
\text { downregulation of miRNA-145 }\end{array}$ & [244] \\
\hline
\end{tabular}

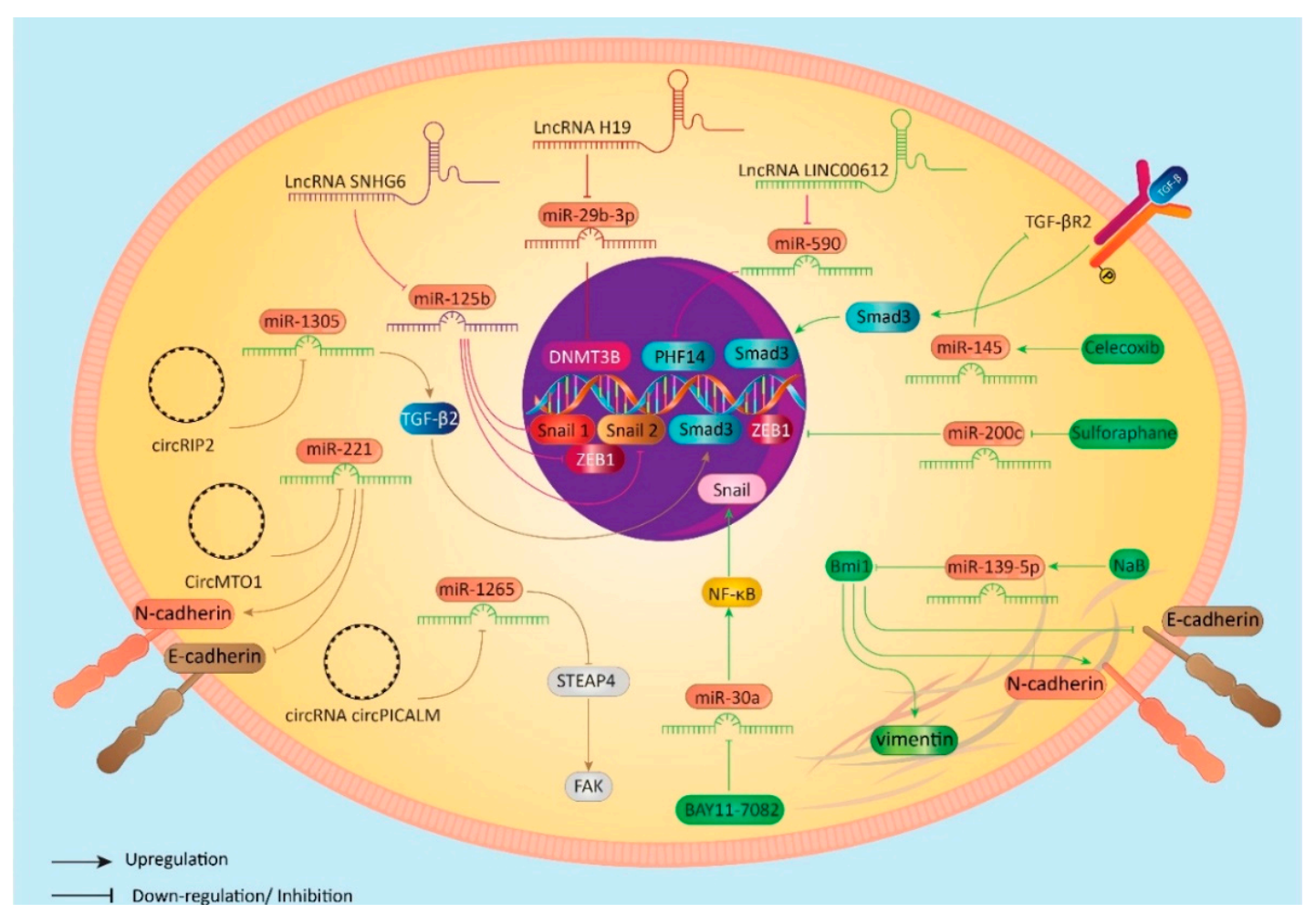

Figure 3. Regulation of miRNA/EMT axis in BC cells. 


\section{Conclusions and Future Directions}

Based on the role of miRNAs in regulation of different cellular events, a disturbance in their expression leads to development of pathological events, particularly cancer. miRNAs have been under attention for regulating both proliferation and invasion of $\mathrm{BC}$ cells, and to date, a substantial number of studies have identified oncogene and onco-suppressor miRNAs in BC cells [22,25,211,245-248]. On the other hand, EMT can act as a downstream target of miRNAs in BC. EMT considerably enhances metastasis and migration of $\mathrm{BC}$ cells, and its targeting is of importance in suppressing invasion of $\mathrm{BC}$ cells and thereby providing desirable prognosis. In the present review, we have provided a comprehensive review about role of miRNAs in regulation of EMT in BC cells. We have divided discussion section into three parts including onco-suppressor miRNAs in EMT inhibition, oncogene miRNAs in EMT induction, and regulation of miRNAs by other molecular pathways such as lncRNAs, circRNAs, etc. Each of the above-mentioned section has investigated a unique signaling pathway in which miRNAs can function as key players regulating tumorigenesis. Targeting these molecular pathways can be considered as an efficient therapeutic strategy in suppressing EMT in BC cells and elevating overall survival of patients with BC.

Author Contributions: Conceptualization, A.Z. and G.S.; methodology, A.P.K.; software, M.A.; validation, A.Z., R.M.; M.E.A.; M.A. and G.S.; formal analysis, K.H.; investigation, M.H.; resources, M.S.; data curation, M.A.; writing-original draft preparation, M.A.; K.H.; writing—review and editing, P.K.; M.R.; visualization, L.K.; supervision, G.S.; project administration, M.A., M.N.; funding acquisition, G.S.; A.P.K. All authors have read and agreed to the published version of the manuscript.

Funding: A.P.K. is supported by the National Medical Research Council of Singapore. A.P.K is also supported by the National Medical Research Council of Singapore and the Singapore Ministry of Education under its Research Centres of Excellence initiative to Cancer Science Institute of Singapore, National University of Singapore. This work was also supported by National University Health System Seed Fund (R-184-000-301-114) to GS.

Conflicts of Interest: The authors declare no conflict of interest.

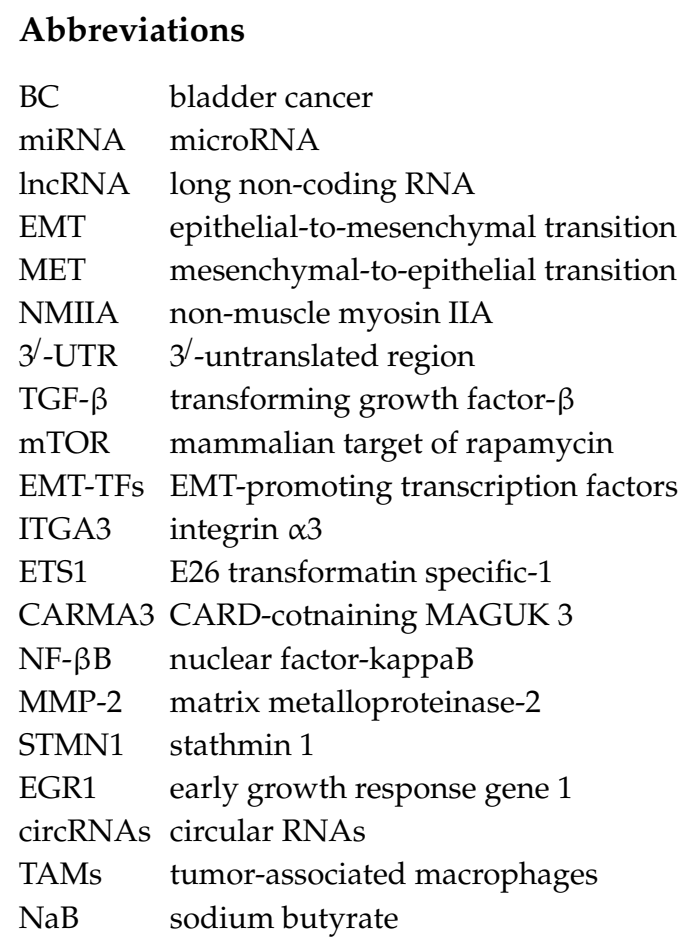

\section{References}

1. Babjuk, M.; Burger, M.; Compérat, E.M.; Gontero, P.; Mostafid, A.H.; Palou, J.; van Rhijn, B.W.; Rouprêt, M.; Shariat, S.F.; Sylvester, R. European Association of Urology guidelines on non-muscle-invasive bladder cancer (TaT1 and carcinoma in situ)—2019 update. Eur. Urol. 2019, 76. [CrossRef] [PubMed] 
2. Alifrangis, C.; McGovern, U.; Freeman, A.; Powles, T.; Linch, M. Molecular and histopathology directed therapy for advanced bladder cancer. Nat. Rev. Urol. 2019, 16, 465-483. [CrossRef] [PubMed]

3. Ferlay, J.; Soerjomataram, I.; Ervik, M.; Dikshit, R.; Eser, S.; Mathers, C. GLOBOCAN 2012: Estimated Cancer Incidence, Mortality and Prevalence Worldwide in 2012; IARC Publications: Lyon, France, 2013.

4. Burger, M.; Catto, J.W.; Dalbagni, G.; Grossman, H.B.; Herr, H.; Karakiewicz, P.; Kassouf, W.; Kiemeney, L.A.; La Vecchia, C.; Shariat, S. Epidemiology and risk factors of urothelial bladder cancer. Eur. Urol. 2013, 63, 234-241. [CrossRef]

5. Chavan, S.; Bray, F.; Lortet-Tieulent, J.; Goodman, M.; Jemal, A. International variations in bladder cancer incidence and mortality. Eur. Urol. 2014, 66, 59-73. [CrossRef] [PubMed]

6. Ashrafizadeh, M.; Zarrabi, A.; Samarghandian, S.; Najafi, M. PTEN: What we know of the function and regulation of this onco-suppressor factor in bladder cancer? Eur. J. Pharmacol. 2020, 881, 173226. [CrossRef]

7. Van Osch, F.H.; Jochems, S.H.; Van Schooten, F.-J.; Bryan, R.T.; Zeegers, M.P. Quantified relations between exposure to tobacco smoking and bladder cancer risk: A meta-analysis of 89 observational studies. Int. J. Epidemiol. 2016, 45, 857-870. [CrossRef]

8. Colt, J.S.; Friesen, M.C.; Stewart, P.A.; Donguk, P.; Johnson, A.; Schwenn, M.; Karagas, M.R.; Armenti, K.; Waddell, R.; Verrill, C. A case-control study of occupational exposure to metalworking fluids and bladder cancer risk among men. Occup. Environ. Med. 2014, 71, 667-674. [CrossRef]

9. Egbers, L.; Grotenhuis, A.J.; Aben, K.K.; Alfred Witjes, J.; Kiemeney, L.A.; Vermeulen, S.H. The prognostic value of family history among patients with urinary bladder cancer. Int. J. Cancer 2015, 136, 1117-1124. [CrossRef]

10. Al-Zalabani, A.H.; Stewart, K.F.; Wesselius, A.; Schols, A.M.; Zeegers, M.P. Modifiable risk factors for the prevention of bladder cancer: A systematic review of meta-analyses. Eur. J. Epidemiol. 2016, 31, 811-851. [CrossRef]

11. Steinmaus, C.; Ferreccio, C.; Acevedo, J.; Yuan, Y.; Liaw, J.; Durán, V.; Cuevas, S.; García, J.; Meza, R.; Valdés, R. Increased lung and bladder cancer incidence in adults after in utero and early-life arsenic exposure. Cancer Epidemiol. Prev. Biomark. 2014, 23, 1529-1538. [CrossRef]

12. Tuccori, M.; Filion, K.B.; Yin, H.; Oriana, H.Y.; Platt, R.W.; Azoulay, L. Pioglitazone use and risk of bladder cancer: Population based cohort study. BMJ 2016, 352, i1541. [CrossRef] [PubMed]

13. Alanee, S.; Alvarado-Cabrero, I.; Murugan, P.; Kumar, R.; Nepple, K.G.; Paner, G.P.; Patel, M.I.; Raspollini, M.R.; Lopez-Beltran, A.; Konety, B.R. Update of the International Consultation on Urological Diseases on bladder cancer 2018: Non-urothelial cancers of the urinary bladder. World J. Urol. 2019, 37, 107-114. [CrossRef] [PubMed]

14. Humphrey, P.A.; Moch, H.; Cubilla, A.L.; Ulbright, T.M.; Reuter, V.E. The 2016 WHO classification of tumours of the urinary system and male genital organs-Part B: Prostate and bladder tumours. Eur. Urol. 2016, 70, 106-119. [CrossRef] [PubMed]

15. Gong, H.; Chen, W.; Mi, L.; Wang, D.; Zhao, Y.; Yu, C.; Zhao, A. Qici Sanling decoction suppresses bladder cancer growth by inhibiting the Wnt/B-catenin pathway. Pharm. Biol. 2019, 57, 507-513. [CrossRef] [PubMed]

16. Sun, N.; Liang, Y.; Chen, Y.; Wang, L.; Li, D.; Liang, Z.; Sun, L.; Wang, Y.; Niu, H. Glutamine affects T24 bladder cancer cell proliferation by activating STAT3 through ROS and glutaminolysis. Int. J. Mol. Med. 2019, 44, 2189-2200. [CrossRef] [PubMed]

17. Li, T.; Jiang, D.; Wu, K. p62 promotes bladder cancer cell growth by activating KEAP1/NRF2-dependent antioxidative response. Cancer Sci. 2020, 111, 1156-1164. [CrossRef]

18. Goan, Y.G.; Wu, W.T.; Liu, C.I.; Neoh, C.A.; Wu, Y.J. Involvement of Mitochondrial Dysfunction, Endoplasmic Reticulum Stress, and the PI3K/AKT/mTOR Pathway in Nobiletin-Induced Apoptosis of Human Bladder Cancer Cells. Molecules 2019, 24. [CrossRef]

19. Zhao, X.; Wang, D.; Ding, Y.; Zhou, J.; Liu, G.; Ji, Z. lncRNA ZEB1-AS1 promotes migration and metastasis of bladder cancer cells by post-transcriptional activation of ZEB1. Int. J. Mol. Med. 2019, 44, 196-206. [CrossRef]

20. Bai, J.; Xu, J.; Zhao, J.; Zhang, R. Downregulation of lncRNA AWPPH inhibits colon cancer cell proliferation by downregulating GLUT-1. Oncology Lett. 2019, 18, 2007-2012. [CrossRef]

21. Zhu, Q.L.; Zhan, D.M.; Chong, Y.K.; Ding, L.; Yang, Y.G. MiR-652-3p promotes bladder cancer migration and invasion by targeting KCNN3. Eur. Rev. Med. Pharm. Sci. 2019, 23, 8806-8812. [CrossRef] 
22. Lu, Q.; Liu, T.; Feng, H.; Yang, R.; Zhao, X.; Chen, W.; Jiang, B.; Qin, H.; Guo, X.; Liu, M.; et al. Circular RNA circSLC8A1 acts as a sponge of miR-130b/miR-494 in suppressing bladder cancer progression via regulating PTEN. Mol. Cancer 2019, 18, 111. [CrossRef] [PubMed]

23. Li, F.; Yang, C.; Zhang, H.B.; Ma, J.; Jia, J.; Tang, X.; Zeng, J.; Chong, T.; Wang, X.; He, D.; et al. BET inhibitor JQ1 suppresses cell proliferation via inducing autophagy and activating LKB1/AMPK in bladder cancer cells. Cancer Med. 2019, 8, 4792-4805. [CrossRef] [PubMed]

24. Xie, H.; Huang, H.; Huang, W.; Xie, Z.; Yang, Y.; Wang, F. LncRNA miR143HG suppresses bladder cancer development through inactivating Wnt/ $\beta$-catenin pathway by modulating miR-1275/AXIN2 axis. J. Cell. Physiol. 2019, 234, 11156-11164. [CrossRef] [PubMed]

25. Guo, J.; Zhao, P.; Liu, Z.; Li, Z.; Yuan, Y.; Zhang, X.; Yu, Z.; Fang, J.; Xiao, K. MiR-204-3p Inhibited the Proliferation of Bladder Cancer Cells via Modulating Lactate Dehydrogenase-Mediated Glycolysis. Front. Oncol. 2019, 9, 1242. [CrossRef] [PubMed]

26. Chen, C.; Luo, Y.; He, W.; Zhao, Y.; Kong, Y.; Liu, H.; Zhong, G.; Li, Y.; Li, J.; Huang, J.; et al. Exosomal long noncoding RNA LNMAT2 promotes lymphatic metastasis in bladder cancer. J. Clin. Investig. 2020, 130, 404-421. [CrossRef] [PubMed]

27. Yoshida, K.; Tsuda, M.; Matsumoto, R.; Semba, S.; Wang, L.; Sugino, H.; Tanino, M.; Kondo, T.; Tanabe, K.; Tanaka, S. Exosomes containing ErbB2/CRK induce vascular growth in premetastatic niches and promote metastasis of bladder cancer. Cancer Sci. 2019, 110, 2119-2132. [CrossRef]

28. Sun, P.; Wu, T.; Sun, X.; Cui, Z.; Zhang, H.; Xia, Q.; Zhang, D. KMT2D inhibits the growth and metastasis of bladder Cancer cells by maintaining the tumor suppressor genes. Biomed. Pharm. 2019, 115, 108924. [CrossRef]

29. Chen, Z.; Du, Y.; Liu, X.; Chen, H.; Weng, X.; Guo, J.; Wang, M.; Wang, X.; Wang, L. EZH2 inhibition suppresses bladder cancer cell growth and metastasis via the JAK2/STAT3 signaling pathway. Oncol. Lett. 2019, 18, 907-915. [CrossRef]

30. Lu, J.J.; Su, Y.W.; Wang, C.J.; Li, D.F.; Zhou, L. Semaphorin 4D promotes the proliferation and metastasis of bladder cancer by activating the PI3K/AKT pathway. Tumori 2019, 105, 231-242. [CrossRef]

31. Rodriguez-Aznar, E.; Wiesmüller, L.; Sainz, B., Jr.; Hermann, P.C. EMT and Stemness-Key Players in Pancreatic Cancer Stem Cells. Cancers 2019, 11. [CrossRef]

32. Teeuwssen, M.; Fodde, R. Wnt Signaling in Ovarian Cancer Stemness, EMT, and Therapy Resistance. J. Clin. Med. 2019, 8. [CrossRef] [PubMed]

33. Wei, G.Y.; Hu, M.; Zhao, L.; Guo, W.S. MiR-451a suppresses cell proliferation, metastasis and EMT via targeting YWHAZ in hepatocellular carcinoma. Eur. Rev. Med. Pharm. Sci. 2019, 23, 5158-5167. [CrossRef]

34. Li, H.; Song, H.; Yuan, X.; Li, J.; Tang, H. miR-30a reverses TGF- $\beta 2$-induced migration and EMT in posterior capsular opacification by targeting Smad2. Mol. Biol. Rep. 2019, 46, 3899-3907. [CrossRef] [PubMed]

35. He, S.; Li, Z.; Yu, Y.; Zeng, Q.; Cheng, Y.; Ji, W.; Xia, W.; Lu, S. Exosomal miR-499a-5p promotes cell proliferation, migration and EMT via mTOR signaling pathway in lung adenocarcinoma. Exp. Cell Res. 2019, 379, 203-213. [CrossRef] [PubMed]

36. Chi, Y.; Wang, F.; Zhang, T.; Xu, H.; Zhang, Y.; Shan, Z.; Wu, S.; Fan, Q.; Sun, Y. miR-516a-3p inhibits breast cancer cell growth and EMT by blocking the Pygo2/Wnt signalling pathway. J. Cell. Mol. Med. 2019, 23, 6295-6307. [CrossRef]

37. Ochoa, A.E.; Choi, W.; Su, X.; Siefker-Radtke, A.; Czerniak, B.; Dinney, C.; McConkey, D.J. Specific micro-RNA expression patterns distinguish the basal and luminal subtypes of muscle-invasive bladder cancer. Oncotarget 2016, 7, 80164-80174. [CrossRef]

38. Georgakopoulos-Soares, I.; Chartoumpekis, D.V.; Kyriazopoulou, V.; Zaravinos, A. EMT Factors and Metabolic Pathways in Cancer. Front. Oncol. 2020, 10, 499. [CrossRef]

39. Ko, J.-H.; Yang, M.H.; Baek, S.H.; Nam, D.; Jung, S.H.; Ahn, K.S. Theacrine attenuates epithelial mesenchymal transition in human breast cancer MDA-MB-231 cells. Phytotherapy Research 2019, 33, 1934-1942. [CrossRef]

40. Mohammadinejad, R.; Biagioni, A.; Arunkumar, G.; Shapiro, R.; Chang, K.-C.; Sedeeq, M.; Taiyab, A.; Hashemabadi, M.; Pardakhty, A.; Mandegary, A.; et al. EMT signaling: Potential contribution of CRISPR/Cas gene editing. Cell. Mol. Life Sci. 2020. [CrossRef]

41. Loh, C.-Y.; Chai, J.Y.; Tang, T.F.; Wong, W.F.; Sethi, G.; Shanmugam, M.K.; Chong, P.P.; Looi, C.Y. The E-Cadherin and N-Cadherin Switch in Epithelial-to-Mesenchymal Transition: Signaling, Therapeutic Implications, and Challenges. Cells 2019, 8, 1118. [CrossRef] 
42. Cheng, J.T.; Wang, L.; Wang, H.; Tang, F.R.; Cai, W.Q.; Sethi, G.; Xin, H.W.; Ma, Z. Insights into Biological Role of LncRNAs in Epithelial-Mesenchymal Transition. Cells 2019, 8. [CrossRef] [PubMed]

43. Ashrafizadeh, M.; Zarrabi, A.; Hushmandi, K.; Kalantari, M.; Mohammadinejad, R.; Javaheri, T.; Sethi, G. Association of the Epithelial-Mesenchymal Transition (EMT) with Cisplatin Resistance. Int. J. Mol. Sci. 2020, 21. [CrossRef] [PubMed]

44. Thiery, J.P.; Acloque, H.; Huang, R.Y.; Nieto, M.A. Epithelial-mesenchymal transitions in development and disease. Cell 2009, 139, 871-890. [CrossRef] [PubMed]

45. Zeisberg, M.; Neilson, E.G. Biomarkers for epithelial-mesenchymal transitions. J. Clin. Investig. 2009, 119, 1429-1437. [CrossRef] [PubMed]

46. Mani, S.A.; Guo, W.; Liao, M.J.; Eaton, E.N.; Ayyanan, A.; Zhou, A.Y.; Brooks, M.; Reinhard, F.; Zhang, C.C.; Shipitsin, M.; et al. The epithelial-mesenchymal transition generates cells with properties of stem cells. Cell 2008, 133, 704-715. [CrossRef]

47. Morel, A.P.; Lièvre, M.; Thomas, C.; Hinkal, G.; Ansieau, S.; Puisieux, A. Generation of breast cancer stem cells through epithelial-mesenchymal transition. PLoS ONE 2008, 3, e2888. [CrossRef]

48. Kalluri, R.; Weinberg, R.A. The basics of epithelial-mesenchymal transition. J. Clin. Investig. 2009, 119, 1420-1428. [CrossRef]

49. Tentler, D.; Lomert, E.; Novitskaya, K.; Barlev, N.A. Role of ACTN4 in Tumorigenesis, Metastasis, and EMT. Cells 2019, 8. [CrossRef]

50. Kim, H.; Lee, S.; Shin, E.; Seong, K.M.; Jin, Y.W.; Youn, H.; Youn, B. The Emerging Roles of Exosomes as EMT Regulators in Cancer. Cells 2020, 9. [CrossRef]

51. Pattabiraman, D.R.; Bierie, B.; Kober, K.I.; Thiru, P.; Krall, J.A.; Zill, C.; Reinhardt, F.; Tam, W.L.; Weinberg, R.A. Activation of PKA leads to mesenchymal-to-epithelial transition and loss of tumor-initiating ability. Science 2016, 351, aad3680. [CrossRef]

52. Zhu, X.; Chen, L.; Liu, L.; Niu, X. EMT-Mediated Acquired EGFR-TKI Resistance in NSCLC: Mechanisms and Strategies. Front. Oncol. 2019, 9, 1044. [CrossRef] [PubMed]

53. Briem, E.; Ingthorsson, S.; Traustadottir, G.A.; Hilmarsdottir, B.; Gudjonsson, T. Application of the D492 Cell Lines to Explore Breast Morphogenesis, EMT and Cancer Progression in 3D Culture. J. Mammary Gland Biol. Neoplasia 2019, 24, 139-147. [CrossRef] [PubMed]

54. Wu, H.T.; Zhong, H.T.; Li, G.W.; Shen, J.X.; Ye, Q.Q.; Zhang, M.L.; Liu, J. Oncogenic functions of the EMT-related transcription factor ZEB1 in breast cancer. J. Trans. Med. 2020, 18, 51. [CrossRef] [PubMed]

55. Lee, J.H.; Chinnathambi, A.; Alharbi, S.A.; Shair, O.H.M.; Sethi, G.; Ahn, K.S. Farnesol abrogates epithelial to mesenchymal transition process through regulating Akt/mTOR pathway. Pharm. Res. 2019, 150, 104504. [CrossRef] [PubMed]

56. Prasannan, R.; Kalesh, K.A.; Shanmugam, M.K.; Nachiyappan, A.; Ramachandran, L.; Nguyen, A.H.; Kumar, A.P.; Lakshmanan, M.; Ahn, K.S.; Sethi, G. Key cell signaling pathways modulated by zerumbone: Role in the prevention and treatment of cancer. Biochem. Pharmacol. 2012, 84, 1268-1276. [CrossRef]

57. Zhu, J.; Zheng, Y.; Zhang, H.; Liu, Y.; Sun, H.; Zhang, P. Galectin-1 induces metastasis and epithelial-mesenchymal transition (EMT) in human ovarian cancer cells via activation of the MAPK JNK/p38 signalling pathway. Am. J. Trans. Res. 2019, 11, 3862-3878.

58. Baek, S.H.; Ko, J.H.; Lee, J.H.; Kim, C.; Lee, H.; Nam, D.; Lee, J.; Lee, S.G.; Yang, W.M.; Um, J.Y.; et al. Ginkgolic Acid Inhibits Invasion and Migration and TGF- $\beta$-Induced EMT of Lung Cancer Cells Through PI3K/Akt/mTOR Inactivation. J. Cell. Physiol. 2017, 232, 346-354. [CrossRef]

59. Ko, J.-H.; Nam, D.; Um, J.-Y.; Jung, S.H.; Sethi, G.; Ahn, K.S. Bergamottin Suppresses Metastasis of Lung Cancer Cells through Abrogation of Diverse Oncogenic Signaling Cascades and Epithelial-to-Mesenchymal Transition. Molecules 2018, 23, 1601. [CrossRef]

60. Steinbichler, T.B.; Dudás, J.; Riechelmann, H.; Skvortsova, I.-I. The role of exosomes in cancer metastasis. Semin. Cancer Biol. 2017, 44, 170-181. [CrossRef]

61. Li, H.; Li, J.; Chen, L.; Qi, S.; Yu, S.; Weng, Z.; Hu, Z.; Zhou, Q.; Xin, Z.; Shi, L.; et al. HERC3-Mediated SMAD7 Ubiquitination Degradation Promotes Autophagy-Induced EMT and Chemoresistance in Glioblastoma. Clin. Cancer Res. Off. J. Am. Assoc. Cancer Res. 2019, 25, 3602-3616. [CrossRef]

62. Thege, F.I.; Gruber, C.N.; Cardle, I.I.; Cong, S.H.; Lannin, T.B.; Kirby, B.J. anti-EGFR capture mitigates EMT- and chemoresistance-associated heterogeneity in a resistance-profiling CTC platform. Anal. Biochem. 2019, 577, 26-33. [CrossRef] [PubMed] 
63. Jordan, N.V.; Johnson, G.L.; Abell, A.N. Tracking the intermediate stages of epithelial-mesenchymal transition in epithelial stem cells and cancer. Cell Cycle 2011, 10, 2865-2873. [CrossRef] [PubMed]

64. Hong, T.; Watanabe, K.; Ta, C.H.; Villarreal-Ponce, A.; Nie, Q.; Dai, X. An Ovol2-Zeb1 Mutual Inhibitory Circuit Governs Bidirectional and Multi-step Transition between Epithelial and Mesenchymal States. PLoS Comput. Biol. 2015, 11, e1004569. [CrossRef] [PubMed]

65. Nieto, M.A.; Huang, R.Y.; Jackson, R.A.; Thiery, J.P. EMT: 2016. Cell 2016, 166, 21-45. [CrossRef] [PubMed]

66. Lambert, A.W.; Pattabiraman, D.R.; Weinberg, R.A. Emerging Biological Principles of Metastasis. Cell 2017, 168, 670-691. [CrossRef]

67. Cook, D.P.; Vanderhyden, B.C. Ovarian cancer and the evolution of subtype classifications using transcriptional profiling. Biol. Reprod. 2019, 101, 645-658. [CrossRef]

68. Kröger, C.; Afeyan, A.; Mraz, J.; Eaton, E.N.; Reinhardt, F.; Khodor, Y.L.; Thiru, P.; Bierie, B.; Ye, X.; Burge, C.B.; et al. Acquisition of a hybrid E/M state is essential for tumorigenicity of basal breast cancer cells. Proc. Natl. Acad. Sci. USA 2019, 116, 7353-7362. [CrossRef]

69. Jolly, M.K.; Boareto, M.; Huang, B.; Jia, D.; Lu, M.; Ben-Jacob, E.; Onuchic, J.N.; Levine, H. Implications of the Hybrid Epithelial/Mesenchymal Phenotype in Metastasis. Front. Oncol. 2015, 5, 155. [CrossRef]

70. Pastushenko, I.; Brisebarre, A.; Sifrim, A.; Fioramonti, M.; Revenco, T.; Boumahdi, S.; Van Keymeulen, A.; Brown, D.; Moers, V.; Lemaire, S.; et al. Identification of the tumour transition states occurring during EMT. Nature 2018, 556, 463-468. [CrossRef]

71. Lazar, M.A.; Birnbaum, M.J. Physiology. De-meaning of metabolism. Science 2012, 336, 1651-1652. [CrossRef]

72. Baenke, F.; Peck, B.; Miess, H.; Schulze, A. Hooked on fat: The role of lipid synthesis in cancer metabolism and tumour development. Dis. Models Mech. 2013, 6, 1353-1363. [CrossRef] [PubMed]

73. Vaupel, P.; Schmidberger, H.; Mayer, A. The Warburg effect: Essential part of metabolic reprogramming and central contributor to cancer progression. Int. J. Radiat. Biol. 2019, 95, 912-919. [CrossRef] [PubMed]

74. Li, L.; Li, W. Epithelial-mesenchymal transition in human cancer: Comprehensive reprogramming of metabolism, epigenetics, and differentiation. Pharm. Ther. 2015, 150, 33-46. [CrossRef] [PubMed]

75. Bhowmik, S.K.; Ramirez-Peña, E.; Arnold, J.M.; Putluri, V.; Sphyris, N.; Michailidis, G.; Putluri, N.; Ambs, S.; Sreekumar, A.; Mani, S.A. EMT-induced metabolite signature identifies poor clinical outcome. Oncotarget 2015, 6, 42651-42660. [CrossRef] [PubMed]

76. Shen, Y.; Chen, Q.; Li, L. Endostar regulates EMT, migration and invasion of lung cancer cells through the HGF-Met pathway. Mol. Cell. Probes 2019, 45, 57-64. [CrossRef]

77. Tan, S.M.; Li, F.; Rajendran, P.; Kumar, A.P.; Hui, K.M.; Sethi, G. Identification of $\beta$-escin as a novel inhibitor of signal transducer and activator of transcription 3/Janus-activated kinase 2 signaling pathway that suppresses proliferation and induces apoptosis in human hepatocellular carcinoma cells. J. Pharmacol. Exp. Ther. 2010, 334, 285-293. [CrossRef]

78. Kim, C.; Cho, S.K.; Kapoor, S.; Kumar, A.; Vali, S.; Abbasi, T.; Kim, S.H.; Sethi, G.; Ahn, K.S. $\beta$-Caryophyllene oxide inhibits constitutive and inducible STAT3 signaling pathway through induction of the SHP-1 protein tyrosine phosphatase. Mol. Carcinog. 2014, 53, 793-806. [CrossRef]

79. Liang, F.; Ren, C.; Wang, J.; Wang, S.; Yang, L.; Han, X.; Chen, Y.; Tong, G.; Yang, G. The crosstalk between STAT3 and p53/RAS signaling controls cancer cell metastasis and cisplatin resistance via the Slug/MAPK/PI3K/AKT-mediated regulation of EMT and autophagy. Oncogenesis 2019, 8, 59. [CrossRef]

80. Zhou, P.; Li, Y.; Li, B.; Zhang, M.; Liu, Y.; Yao, Y.; Li, D. NMIIA promotes tumor growth and metastasis by activating the Wnt/ $\beta$-catenin signaling pathway and EMT in pancreatic cancer. Oncogene 2019, 38, 5500-5515. [CrossRef]

81. Meng, H.; Wu, J.; Huang, Q.; Yang, X.; Yang, K.; Qiu, Y.; Ren, J.; Shen, R.; Qi, H. NEDD9 promotes invasion and migration of colorectal cancer cell line HCT116 via JNK/EMT. Oncol. Lett. 2019, 18, 4022-4029. [CrossRef]

82. Yan, H.; Li, H.; Silva, M.A.; Guan, Y.; Yang, L.; Zhu, L.; Zhang, Z.; Li, G.; Ren, C. LncRNA FLVCR1-AS1 mediates miR-513/YAP1 signaling to promote cell progression, migration, invasion and EMT process in ovarian cancer. J. Exp. Clin. Cancer Res. 2019, 38, 356. [CrossRef] [PubMed]

83. Zhang, J.; Chu, D.; Kawamura, T.; Tanaka, K.; He, S. GRIM-19 repressed hypoxia-induced invasion and EMT of colorectal cancer by repressing autophagy through inactivation of STAT3/HIF- $1 \alpha$ signaling axis. J. Cell. Physiol. 2019, 234, 12800-12808. [CrossRef] [PubMed] 
84. Zhou, J.; Du, Y.; Lu, Y.; Luan, B.; Xu, C.; Yu, Y.; Zhao, H. CD44 Expression Predicts Prognosis of Ovarian Cancer Patients Through Promoting Epithelial-Mesenchymal Transition (EMT) by Regulating Snail, ZEB1, and Caveolin-1. Front. Oncol. 2019, 9, 802. [CrossRef] [PubMed]

85. Tian, S.; Peng, P.; Li, J.; Deng, H.; Zhan, N.; Zeng, Z.; Dong, W. SERPINH1 regulates EMT and gastric cancer metastasis via the $\mathrm{Wnt} / \beta$-catenin signaling pathway. Aging 2020, 12, 3574-3593. [CrossRef] [PubMed]

86. Wang, J.R.; Liu, B.; Zhou, L.; Huang, Y.X. MicroRNA-124-3p suppresses cell migration and invasion by targeting ITGA3 signaling in bladder cancer. Cancer Biomark. Sect. A Dis. Mark. 2019, 24, 159-172. [CrossRef]

87. Wu, Y.; Hu, G.; Wu, R.; Gong, N. High expression of miR-135b predicts malignant transformation and poor prognosis of gastric cancer. Life Sci. 2020, 257, 118133. [CrossRef]

88. Ravegnini, G.; Cargnin, S.; Sammarini, G.; Zanotti, F.; Bermejo, J.L.; Hrelia, P.; Terrazzino, S.; Angelini, S. Prognostic Role of miR-221 and miR-222 Expression in Cancer Patients: A Systematic Review and Meta-Analysis. Cancers 2019, 11, 970. [CrossRef]

89. Xiao, Y.; Humphries, B.; Yang, C.; Wang, Z. MiR-205 Dysregulations in Breast Cancer: The Complexity and Opportunities. Noncoding RNA 2019, 5, 53. [CrossRef]

90. Gulei, D.; Raduly, L.; Broseghini, E.; Ferracin, M.; Berindan-Neagoe, I. The extensive role of miR-155 in malignant and non-malignant diseases. Mol. Asp. Med. 2019, 70, 33-56. [CrossRef]

91. Taddei, M.L.; Cavallini, L.; Ramazzotti, M.; Comito, G.; Pietrovito, L.; Morandi, A.; Giannoni, E.; Raugei, G.; Chiarugi, P. Stromal-induced downregulation of miR-1247 promotes prostate cancer malignancy. J. Cell. Physiol. 2019, 234, 8274-8285. [CrossRef]

92. Pan, Y.J.; Wan, J.; Wang, C.B. MiR-326: Promising Biomarker for Cancer. Cancer Manag. Res. 2019, 11, 10411-10418. [CrossRef] [PubMed]

93. Chen, W.; Song, J.; Bian, H.; Yang, X.; Xie, X.; Zhu, Q.; Qin, C.; Qi, J. The functions and targets of miR-212 as a potential biomarker of cancer diagnosis and therapy. J. Cell. Mol. Med. 2020, 24, 2392-2401. [CrossRef] [PubMed]

94. Yoshimoto, S.; Tanaka, F.; Morita, H.; Hiraki, A.; Hashimoto, S. Hypoxia-induced HIF-1 $\alpha$ and ZEB1 are critical for the malignant transformation of ameloblastoma via TGF- $\beta$-dependent EMT. Cancer Med. 2019, 8 , 7822-7832. [CrossRef] [PubMed]

95. Zeng, Y.; Gao, T.; Huang, W.; Yang, Y.; Qiu, R.; Hou, Y.; Yu, W.; Leng, S.; Feng, D.; Liu, W.; et al. MicroRNA-455-3p mediates GATA3 tumor suppression in mammary epithelial cells by inhibiting TGF- $\beta$ signaling. J. Biol. Chem. 2019, 294, 15808-15825. [CrossRef]

96. Yi, J.; Fan, Y.; Zhang, L.; Wang, H.; Mu, T.; Xie, H.; Gao, H.; Liu, M.; Li, S.; Tang, H. MiR-HCC2 Up-regulates BAMBI and ELMO1 Expression to Facilitate the Proliferation and EMT of Hepatocellular Carcinoma Cells. J. Cancer 2019, 10, 3407-3419. [CrossRef]

97. Koshizuka, K.; Hanazawa, T.; Kikkawa, N.; Arai, T.; Okato, A.; Kurozumi, A.; Kato, M.; Katada, K.; Okamoto, Y.; Seki, N. Regulation of ITGA3 by the anti-tumor miR-199 family inhibits cancer cell migration and invasion in head and neck cancer. Cancer Sci. 2017, 108, 1681-1692. [CrossRef]

98. Sa, K.D.; Zhang, X.; Li, X.F.; Gu, Z.P.; Yang, A.G.; Zhang, R.; Li, J.P.; Sun, J.Y. A miR-124/ITGA3 axis contributes to colorectal cancer metastasis by regulating anoikis susceptibility. Biochem. Biophys. Res. Commun. 2018, 501, 758-764. [CrossRef]

99. Yan, T.; Ye, X.X. MicroRNA-328-3p inhibits the tumorigenesis of bladder cancer through targeting ITGA5 and inactivating PI3K/AKT pathway. Eur. Rev. Med. Pharm. Sci. 2019, 23, 5139-5148. [CrossRef]

100. Mohan, C.D.; Srinivasa, V.; Rangappa, S.; Mervin, L.; Mohan, S.; Paricharak, S.; Baday, S.; Li, F.; Shanmugam, M.K.; Chinnathambi, A.; et al. Trisubstituted-imidazoles induce apoptosis in human breast cancer cells by targeting the oncogenic PI3K/Akt/mTOR signaling pathway. PLoS ONE 2016, 11, e0153155. [CrossRef]

101. Ong, P.S.; Wang, L.Z.; Dai, X.; Tseng, S.H.; Loo, S.J.; Sethi, G. Judicious Toggling of mTOR Activity to Combat Insulin Resistance and Cancer: Current Evidence and Perspectives. Front. Pharmacol. 2016, 7, 395. [CrossRef]

102. Siveen, K.S.; Ahn, K.S.; Ong, T.H.; Shanmugam, M.K.; Li, F.; Yap, W.N.; Kumar, A.P.; Fong, C.W.; Tergaonkar, V.; Hui, K.M.; et al. Y-tocotrienol inhibits angiogenesis-dependent growth of human hepatocellular carcinoma through abrogation of AKT/mTOR pathway in an orthotopic mouse model. Oncotarget 2014, 5, 1897-1911. [CrossRef] [PubMed] 
103. Hou, T.; Zhou, L.; Wang, L.; Kazobinka, G.; Chen, Y.; Zhang, X.; Chen, Z. Leupaxin Promotes Bladder Cancer Proliferation, Metastasis, and Angiogenesis Through the PI3K/AKT Pathway. Cell. Physiol. Biochem. 2018, 47, 2250-2260. [CrossRef] [PubMed]

104. Zhang, L.; Qiang, J.; Yang, X.; Wang, D.; Rehman, A.U.; He, X.; Chen, W.; Sheng, D.; Zhou, L.; Jiang, Y.Z.; et al. IL1R2 Blockade Suppresses Breast Tumorigenesis and Progression by Impairing USP15-Dependent BMI1 Stability. Adv. Sci. 2020, 7, 1901728. [CrossRef] [PubMed]

105. Li, K.; Ma, Y.B.; Tian, Y.H.; Xu, X.L.; Gao, Y.; He, Y.Q.; Pan, W.T.; Zhang, J.W.; He, C.J.; Wei, L. Silencing lncRNA SNHG6 suppresses proliferation and invasion of breast cancer cells through miR-26a/VASP axis. Pathol. Res. Pract. 2019, 215, 152575. [CrossRef]

106. Zhang, L.; Wang, C.Z.; Ma, M.; Shao, G.F. MiR-15 suppressed the progression of bladder cancer by targeting BMI1 oncogene via PI3K/AKT signaling pathway. Eur. Rev. Med. Pharm. Sci. 2019, 23, 8813-8822. [CrossRef]

107. Guo, C.C.; Majewski, T.; Zhang, L.; Yao, H.; Bondaruk, J.; Wang, Y.; Zhang, S.; Wang, Z.; Lee, J.G.; Lee, S.; et al. Dysregulation of EMT Drives the Progression to Clinically Aggressive Sarcomatoid Bladder Cancer. Cell Rep. 2019, 27, 1781-1793. [CrossRef]

108. Liu, X.; Xu, X.; Deng, W.; Huang, M.; Wu, Y.; Zhou, Z.; Zhu, K.; Wang, Y.; Cheng, X.; Zhou, X.; et al. CCL18 enhances migration, invasion and EMT by binding CCR8 in bladder cancer cells. Mol. Med. Rep. 2019, 19, 1678-1686. [CrossRef]

109. Banan, A.; Zhang, L.; Farhadi, A.; Fields, J.; Shaikh, M.; Keshavarzian, A. PKC- $\beta 1$ isoform activation is required for EGF-induced NF- $\kappa \mathrm{B}$ inactivation and $\mathrm{I} \kappa \mathrm{B} \alpha$ stabilization and protection of F-actin assembly and barrier function in enterocyte monolayers. Am. J. Physiol. Cell Physiol. 2004, 286, C723-C738. [CrossRef]

110. McAllister-Lucas, L.M.; Ruland, J.; Siu, K.; Jin, X.; Gu, S.; Kim, D.S.; Kuffa, P.; Kohrt, D.; Mak, T.W.; Nuñez, G. CARMA3/Bcl10/MALT1-dependent NF- $\mathrm{kB}$ activation mediates angiotensin II-responsive inflammatory signaling in nonimmune cells. Proc. Natl. Acad. Sci. USA 2007, 104, 139-144. [CrossRef]

111. Grabiner, B.C.; Blonska, M.; Lin, P.-C.; You, Y.; Wang, D.; Sun, J.; Darnay, B.G.; Dong, C.; Lin, X. CARMA3 deficiency abrogates $G$ protein-coupled receptor-induced NF-kB activation. Genes Dev. 2007, 21, 984-996. [CrossRef]

112. Wang, D.; You, Y.; Lin, P.-C.; Xue, L.; Morris, S.W.; Zeng, H.; Wen, R.; Lin, X. Bcl10 plays a critical role in NF-kB activation induced by G protein-coupled receptors. Proc. Natl. Acad. Sci. USA 2007, 104, 145-150. [CrossRef] [PubMed]

113. Man, X.; Liu, T.; Jiang, Y.; Zhang, Z.; Zhu, Y.; Li, Z.; Kong, C.; He, J. Silencing of CARMA3 inhibits bladder cancer cell migration and invasion via deactivating $\beta$-catenin signaling pathway. Oncotarget. Ther. 2019, 12, 6309-6322. [CrossRef] [PubMed]

114. Zhang, S.; Zhang, C.; Liu, W.; Zheng, W.; Zhang, Y.; Wang, S.; Huang, D.; Liu, X.; Bai, Z. MicroRNA-24 upregulation inhibits proliferation, metastasis and induces apoptosis in bladder cancer cells by targeting CARMA3. Int. J. Oncol. 2015, 47, 1351-1360. [CrossRef] [PubMed]

115. Huang, X.; Zhu, H.; Gao, Z.; Li, J.; Zhuang, J.; Dong, Y.; Shen, B.; Li, M.; Zhou, H.; Guo, H.; et al. Wnt7a activates canonical Wnt signaling, promotes bladder cancer cell invasion, and is suppressed by miR-370-3p. J. Biol. Chem. 2018, 293, 6693-6706. [CrossRef]

116. Chen, Z.; Zhou, L.; Chen, L.; Xiong, M.; Kazobinka, G.; Pang, Z.; Hou, T. RSPO3 promotes the aggressiveness of bladder cancer via Wnt/ $\beta$-catenin and Hedgehog signaling pathways. Carcinogenesis 2019, 40, 360-369. [CrossRef]

117. Bhuvanalakshmi, G.; Gamit, N.; Patil, M.; Arfuso, F.; Sethi, G.; Dharmarajan, A.; Kumar, A.P.; Warrier, S. Stemness, Pluripotentiality, and Wnt Antagonism: sFRP4, a Wnt antagonist Mediates Pluripotency and Stemness in Glioblastoma. Cancers 2018, 11. [CrossRef]

118. Bhuvanalakshmi, G.; Basappa; Rangappa, K.S.; Dharmarajan, A.; Sethi, G.; Kumar, A.P.; Warrier, S. Breast Cancer Stem-Like Cells Are Inhibited by Diosgenin, a Steroidal Saponin, by the Attenuation of the Wnt $\beta$-Catenin Signaling via the Wnt Antagonist Secreted Frizzled Related Protein-4. Front. Pharmacol. 2017, 8. [CrossRef]

119. Ong, M.S.; Cai, W.; Yuan, Y.; Leong, H.C.; Tan, T.Z.; Mohammad, A.; You, M.L.; Arfuso, F.; Goh, B.C.; Warrier, S.; et al. 'Lnc'-ing Wnt in female reproductive cancers: Therapeutic potential of long non-coding RNAs in Wnt signalling. Br. J. Pharmacol. 2017, 174, 4684-4700. [CrossRef]

120. Pang, G.; Xie, Q.; Yao, J. Mitofusin 2 inhibits bladder cancer cell proliferation and invasion via the Wnt/ $\beta$-catenin pathway. Oncol. Lett. 2019, 18, 2434-2442. [CrossRef] 
121. Garg, M.; Maurya, N. WNT/ $\beta$-catenin signaling in urothelial carcinoma of bladder. World J. Nephrol. 2019, 8, 83-94. [CrossRef]

122. Wang, R.; Song, Y.; Liu, X.; Wang, Q.; Wang, Y.; Li, L.; Kang, C.; Zhang, Q. UBE2C induces EMT through Wnt/ $\beta$-catenin and PI3K/Akt signaling pathways by regulating phosphorylation levels of Aurora-A. Int. J. Oncol. 2017, 50, 1116-1126. [CrossRef] [PubMed]

123. Hu, W.; Wang, Z.; Zhang, S.; Lu, X.; Wu, J.; Yu, K.; Ji, A.; Lu, W.; Wang, Z.; Wu, J.; et al. IQGAP1 promotes pancreatic cancer progression and epithelial-mesenchymal transition (EMT) through Wnt/ $\beta$-catenin signaling. Sci. Rep. 2019, 9, 7539. [CrossRef] [PubMed]

124. Zhang, J.; Cai, H.; Sun, L.; Zhan, P.; Chen, M.; Zhang, F.; Ran, Y.; Wan, J. LGR5, a novel functional glioma stem cell marker, promotes EMT by activating the Wnt/ $\beta$-catenin pathway and predicts poor survival of glioma patients. J. Exp. Clin. Cancer Res. CR 2018, 37, 225. [CrossRef] [PubMed]

125. Dai, B.W.; Yang, Z.M.; Deng, P.; Chen, Y.R.; He, Z.J.; Yang, X.; Zhang, S.; Wu, H.J.; Ren, Z.H. HOXC10 promotes migration and invasion via the WNT-EMT signaling pathway in oral squamous cell carcinoma. J. Cancer 2019, 10, 4540-4551. [CrossRef] [PubMed]

126. Wei, C.Y.; Zhu, M.X.; Yang, Y.W.; Zhang, P.F.; Yang, X.; Peng, R.; Gao, C.; Lu, J.C.; Wang, L.; Deng, X.Y.; et al. Downregulation of RNF128 activates Wnt/ $\beta$-catenin signaling to induce cellular EMT and stemness via CD44 and CTTN ubiquitination in melanoma. J. Hematol. Oncol. 2019, 12, 21. [CrossRef]

127. Zhang, Q.; Miao, S.; Han, X.; Li, C.; Zhang, M.; Cui, K.; Xiong, T.; Chen, Z.; Wang, C.; Xu, H. MicroRNA-3619-5p suppresses bladder carcinoma progression by directly targeting $\beta$-catenin and CDK2 and activating p21. Cell Death Dis. 2018, 9, 960. [CrossRef]

128. Hao, Y.; Baker, D.; Ten Dijke, P. TGF- $\beta$-Mediated Epithelial-Mesenchymal Transition and Cancer Metastasis. Int. J. Mol. Sci. 2019, 20. [CrossRef]

129. Alvarez, M.A.; Freitas, J.P.; Mazher Hussain, S.; Glazer, E.S. TGF- $\beta$ Inhibitors in Metastatic Pancreatic Ductal Adenocarcinoma. J. Gastrointest. Cancer 2019, 50, 207-213. [CrossRef]

130. Howley, B.V.; Howe, P.H. TGF-beta signaling in cancer: Post-transcriptional regulation of EMT via hnRNP E1. Cytokine 2019, 118, 19-26. [CrossRef]

131. Jiang, X.; Zhang, Z.; Song, C.; Deng, H.; Yang, R.; Zhou, L.; Sun, Y.; Zhang, Q. Glaucocalyxin A reverses EMT and TGF- $\beta 1$-induced EMT by inhibiting TGF- $\beta 1 / \mathrm{Smad} / 3$ signaling pathway in osteosarcoma. Chem. Biol. Interact. 2019, 307, 158-166. [CrossRef]

132. Yao, Y.; Chen, R.; Wang, G.; Zhang, Y.; Liu, F. Exosomes derived from mesenchymal stem cells reverse EMT via TGF- $31 /$ Smad pathway and promote repair of damaged endometrium. Stem Cell Res. Ther. 2019, 10, 225. [CrossRef] [PubMed]

133. Wei, X.C.; Lv, Z.H. MicroRNA-132 inhibits migration, invasion and epithelial-mesenchymal transition via TGF $\beta 1 /$ Smad2 signaling pathway in human bladder cancer. Oncotarget. Ther. 2019, 12, 5937-5945. [CrossRef] [PubMed]

134. Shen, J.; Hong, L.; Yu, D.; Cao, T.; Zhou, Z.; He, S. LncRNA XIST promotes pancreatic cancer migration, invasion and EMT by sponging miR-429 to modulate ZEB1 expression. Int. J. Biochem. Cell Biol. 2019, 113, 17-26. [CrossRef] [PubMed]

135. Xiao, Y.Y.; Lin, L.; Li, Y.H.; Jiang, H.P.; Zhu, L.T.; Deng, Y.R.; Lin, D.; Chen, W.; Zeng, C.Y.; Wang, L.J.; et al. ZEB1 promotes invasion and metastasis of endometrial cancer by interacting with HDGF and inducing its transcription. Am. J. Cancer Res. 2019, 9, 2314-2330. [PubMed]

136. Majid, S.; Dar, A.A.; Saini, S.; Deng, G.; Chang, I.; Greene, K.; Tanaka, Y.; Dahiya, R.; Yamamura, S. MicroRNA-23b functions as a tumor suppressor by regulating Zeb1 in bladder cancer. PLoS ONE 2013, 8, e67686. [CrossRef] [PubMed]

137. Shi, D.; Wu, F.; Mu, S.; Hu, B.; Zhong, B.; Gao, F.; Qing, X.; Liu, J.; Zhang, Z.; Shao, Z. LncRNA AFAP1-AS1 promotes tumorigenesis and epithelial-mesenchymal transition of osteosarcoma through RhoC/ROCK1/p38MAPK/Twist1 signaling pathway. J. Exp. Clin. Cancer Res. 2019, 38, 375. [CrossRef]

138. Yao, N.; Fu, Y.; Chen, L.; Liu, Z.; He, J.; Zhu, Y.; Xia, T.; Wang, S. Long non-coding RNA NONHSAT101069 promotes epirubicin resistance, migration, and invasion of breast cancer cells through NONHSAT101069/miR-129-5p/Twist1 axis. Oncogene 2019, 38, 7216-7233. [CrossRef]

139. Shen, J.; Zhang, J.; Xiao, M.; Yang, J.; Zhang, N. miR-203 Suppresses Bladder Cancer Cell Growth and Targets Twist1. Oncol. Res. 2018, 26, 1155-1165. [CrossRef] [PubMed] 
140. Chien, M.H.; Lin, Y.W.; Wen, Y.C.; Yang, Y.C.; Hsiao, M.; Chang, J.L.; Huang, H.C.; Lee, W.J. Targeting the SPOCK1-snail/slug axis-mediated epithelial-to-mesenchymal transition by apigenin contributes to repression of prostate cancer metastasis. J. Exp. Clin. Cancer Res. 2019, 38, 246. [CrossRef]

141. Cai, Y.; Dong, Z.Y.; Wang, J.Y. LncRNA NNT-AS1 is a major mediator of cisplatin chemoresistance in non-small cell lung cancer through MAPK/Slug pathway. Eur. Rev. Med. Pharm. Sci. 2018, 22, 4879-4887. [CrossRef]

142. Li, W.; He, Q.Z.; Wu, C.Q.; Pan, X.Y.; Wang, J.; Tan, Y.; Shan, X.Y.; Zeng, H.C. PFOS Disturbs BDNF-ERK-CREB Signalling in Association with Increased MicroRNA-22 in SH-SY5Y Cells. Biomed. Res. Int. 2015, 2015, 302653. [CrossRef] [PubMed]

143. Yang, J.; Fan, Z.; Yang, J.; Ding, J.; Yang, C.; Chen, L. microRNA-22 attenuates myocardial ischemia-reperfusion injury via an anti-inflammatory mechanism in rats. Exp. Ther. Med. 2016, 12, 3249-3255. [CrossRef] [PubMed]

144. Xu, M.; Li, J.; Wang, X.; Meng, S.; Shen, J.; Wang, S.; Xu, X.; Xie, B.; Liu, B.; Xie, L. MiR-22 suppresses epithelial-mesenchymal transition in bladder cancer by inhibiting Snail and MAPK1/Slug/vimentin feedback loop. Cell Death Dis. 2018, 9, 209. [CrossRef] [PubMed]

145. Wang, X.; Liang, Z.; Xu, X.; Li, J.; Zhu, Y.; Meng, S.; Li, S.; Wang, S.; Xie, B.; Ji, A.; et al. miR-148a-3p represses proliferation and EMT by establishing regulatory circuits between ERBB3/AKT2/c-myc and DNMT1 in bladder cancer. Cell Death Dis. 2016, 7, e2503. [CrossRef]

146. Xu, X.; Zhu, Y.; Liang, Z.; Li, S.; Xu, X.; Wang, X.; Wu, J.; Hu, Z.; Meng, S.; Liu, B.; et al. c-Met and CREB1 are involved in miR-433-mediated inhibition of the epithelial-mesenchymal transition in bladder cancer by regulating Akt/GSK-3ß/Snail signaling. Cell Death Dis. 2016, 7, e2088. [CrossRef]

147. Li, J.; Xu, X.; Meng, S.; Liang, Z.; Wang, X.; Xu, M.; Wang, S.; Li, S.; Zhu, Y.; Xie, B.; et al. MET/SMAD3/SNAIL circuit mediated by miR-323a-3p is involved in regulating epithelial-mesenchymal transition progression in bladder cancer. Cell Death Dis. 2017, 8, e3010. [CrossRef]

148. Chen, M.F.; Zeng, F.; Qi, L.; Zu, X.B.; Wang, J.; Liu, L.F.; Li, Y. Transforming growth factor- $\beta 1$ induces epithelial-mesenchymal transition and increased expression of matrix metalloproteinase-16 via miR-200b downregulation in bladder cancer cells. Mol. Med. Rep. 2014, 10, 1549-1554. [CrossRef]

149. Wang, Y.; Ma, D.L.; Yu, C.H.; Sha, K.F.; Zhao, M.J.; Liu, T.J. MicroRNA-370 suppresses SOX12 transcription and acts as a tumor suppressor in bladder cancer. Eur. Rev. Med. Pharm. Sci. 2020, 24, 2303-2312. [CrossRef]

150. Yu, G.; Yao, W.; Xiao, W.; Li, H.; Xu, H.; Lang, B. MicroRNA-34a functions as an anti-metastatic microRNA and suppresses angiogenesis in bladder cancer by directly targeting CD44. J. Exp. Clin. Cancer Res. 2014, 33, 779. [CrossRef]

151. Yu, H.; Duan, P.; Zhu, H.; Rao, D. miR-613 inhibits bladder cancer proliferation and migration through targeting SphK1. Am. J. Trans. Res. 2017, 9, 1213-1221.

152. Yao, K.; He, L.; Gan, Y.; Zeng, Q.; Dai, Y.; Tan, J. MiR-186 suppresses the growth and metastasis of bladder cancer by targeting NSBP1. Diagn. Pathol. 2015, 10, 146. [CrossRef] [PubMed]

153. Zhang, Y.; Zhang, D.; Lv, J.; Wang, S.; Zhang, Q. MiR-125a-5p suppresses bladder cancer progression through targeting FUT4. Biomed. Pharm. 2018, 108, 1039-1047. [CrossRef] [PubMed]

154. Na, X.Y.; Shang, X.S.; Zhao, Y.; Ren, P.P.; Hu, X.Q. MiR-203a functions as a tumor suppressor in bladder cancer by targeting SIX4. Neoplasma 2019, 66, 211-221. [CrossRef] [PubMed]

155. Guo, J.; Zhang, J.; Yang, T.; Zhang, W.; Liu, M. MiR-22 suppresses the growth and metastasis of bladder cancer cells by targeting E2F3. Int. J. Clin. Exp. Pathol. 2020, 13, 587-596.

156. Wang, S.; Zhang, G.; Zheng, W.; Xue, Q.; Wei, D.; Zheng, Y.; Yuan, J. MiR-454-3p and miR-374b-5p suppress migration and invasion of bladder cancer cells through targetting ZEB2. Biosci. Rep. 2018, 38. [CrossRef]

157. Zeng, T.; Peng, L.; Chao, C.; Fu, B.; Wang, G.; Wang, Y.; Zhu, X. miR-451 inhibits invasion and proliferation of bladder cancer by regulating EMT. Int. J. Clin. Exp. Pathol. 2014, 7, 7653-7662.

158. Zhou, M.; Wang, S.; Hu, L.; Liu, F.; Zhang, Q.; Zhang, D. miR-199a-5p suppresses human bladder cancer cell metastasis by targeting CCR7. BMC Urol. 2016, 16, 64. [CrossRef]

159. Li, J.; Qiu, M.; An, Y.; Huang, J.; Gong, C. miR-7-5p acts as a tumor suppressor in bladder cancer by regulating the hedgehog pathway factor Gli3. Biochem. Biophys. Res. Commun. 2018, 503, 2101-2107. [CrossRef]

160. Adam, L.; Zhong, M.; Choi, W.; Qi, W.; Nicoloso, M.; Arora, A.; Calin, G.; Wang, H.; Siefker-Radtke, A.; McConkey, D.; et al. miR-200 expression regulates epithelial-to-mesenchymal transition in bladder cancer cells and reverses resistance to epidermal growth factor receptor therapy. Clin. Cancer Res. Off. J. Am. Assoc. Cancer Res. 2009, 15, 5060-5072. [CrossRef] 
161. Liu, L.; Qiu, M.; Tan, G.; Liang, Z.; Qin, Y.; Chen, L.; Chen, H.; Liu, J. miR-200c inhibits invasion, migration and proliferation of bladder cancer cells through down-regulation of BMI-1 and E2F3. J. Trans. Med. 2014, 12, 305. [CrossRef]

162. Chen, Z.; Li, Q.; Wang, S.; Zhang, J. miR-485-5p inhibits bladder cancer metastasis by targeting HMGA2. Int. J. Mol. Med. 2015, 36, 1136-1142. [CrossRef] [PubMed]

163. Wu, C.L.; Ho, J.Y.; Chou, S.C.; Yu, D.S. MiR-429 reverses epithelial-mesenchymal transition by restoring E-cadherin expression in bladder cancer. Oncotarget 2016, 7, 26593-26603. [CrossRef] [PubMed]

164. Li, J.; Ying, Y.; Xie, H.; Jin, K.; Yan, H.; Wang, S.; Xu, M.; Xu, X.; Wang, X.; Yang, K.; et al. Dual regulatory role of CCNA2 in modulating CDK6 and MET-mediated cell-cycle pathway and EMT progression is blocked by miR-381-3p in bladder cancer. FASEB J. 2019, 33, 1374-1388. [CrossRef]

165. Guttilla, I.K.; Adams, B.D.; White, B.A. ER $\alpha$, microRNAs, and the epithelial-mesenchymal transition in breast cancer. Trends Endocrinol. Metab. 2012, 23, 73-82. [CrossRef] [PubMed]

166. Zhang, H.F.; Xu, L.Y.; Li, E.M. A family of pleiotropically acting microRNAs in cancer progression, miR-200: Potential cancer therapeutic targets. Curr. Pharm. Des. 2014, 20, 1896-1903. [CrossRef]

167. Gao, Y.; Zhang, W.; Liu, C.; Li, G. miR-200 affects tamoxifen resistance in breast cancer cells through regulation of MYB. Sci. Rep. 2019, 9, 18844. [CrossRef]

168. Gregory, P.A.; Bert, A.G.; Paterson, E.L.; Barry, S.C.; Tsykin, A.; Farshid, G.; Vadas, M.A.; Khew-Goodall, Y.; Goodall, G.J. The miR-200 family and miR-205 regulate epithelial to mesenchymal transition by targeting ZEB1 and SIP1. Nat. Cell Biol. 2008, 10, 593-601. [CrossRef]

169. Yang, K.; Tang, H.; Ding, M.; Guo, Y.; Kai, K.; Xiao, J.; Shen, Y.; Miao, S.; Zhou, R. Expression of miR-195 and MEK1 in patients with bladder cancer and their relationship to prognosis. Int. J. Clin. Exp. Pathol. 2019, 12, 843-850.

170. Zhao, C.; Qi, L.; Chen, M.; Liu, L.; Yan, W.; Tong, S.; Zu, X. microRNA-195 inhibits cell proliferation in bladder cancer via inhibition of cell division control protein 42 homolog/signal transducer and activator of transcription-3 signaling. Exp. Ther. Med. 2015, 10, 1103-1108. [CrossRef]

171. Li, H.J.; Sun, X.M.; Li, Z.K.; Yin, Q.W.; Pang, H.; Pan, J.J.; Li, X.; Chen, W. LncRNA UCA1 Promotes Mitochondrial Function of Bladder Cancer via the MiR-195/ARL2 Signaling Pathway. Cell. Physiol. Biochem. 2017, 43, 2548-2561. [CrossRef]

172. Chen, S.; Wang, W.; Lin, G.; Zhong, S. MicroRNA-195 inhibits epithelial-mesenchymal transition via downregulating CDK4 in bladder cancer. Int. J. Clin. Exp. Pathol. 2018, 11, 3891-3902. [PubMed]

173. Liu, L.; Liu, Y.; Zhang, X.; Chen, M.; Wu, H.; Lin, M.; Zhan, Y.; Zhuang, C.; Lin, J.; Li, J.; et al. Inhibiting cell migration and cell invasion by silencing the transcription factor ETS-1 in human bladder cancer. Oncotarget 2016, 7, 25125-25134. [CrossRef] [PubMed]

174. Hui, K.; Wu, S.; Yue, Y.; Gu, Y.; Guan, B.; Wang, X.; Hsieh, J.T.; Chang, L.S.; He, D.; Wu, K. RASAL2 inhibits tumor angiogenesis via p-AKT/ETS1 signaling in bladder cancer. Cell. Signal. 2018, 48, 38-44. [CrossRef]

175. Zhang, L.; Yan, R.; Zhang, S.N.; Zhang, H.Z.; Ruan, X.J.; Cao, Z.; Gu, X.Z. MicroRNA-338-3p inhibits the progression of bladder cancer through regulating ETS1 expression. Eur. Rev. Med. Pharm. Sci. 2019, 23, 1986-1995. [CrossRef]

176. Mao, X.W.; Xiao, J.Q.; Li, Z.Y.; Zheng, Y.C.; Zhang, N. Effects of microRNA-135a on the epithelial-mesenchymal transition, migration and invasion of bladder cancer cells by targeting GSK3 $\beta$ through the Wnt $/ \beta$-catenin signaling pathway. Exp. Mol. Med. 2018, 50, e429. [CrossRef] [PubMed]

177. He, C.; Zhang, Q.; Gu, R.; Lou, Y.; Liu, W. miR-96 regulates migration and invasion of bladder cancer through epithelial-mesenchymal transition in response to transforming growth factor- $\beta 1$. J. Cell. Biochem. 2018, 119, 7807-7817. [CrossRef]

178. Baldassarre, G.; Belletti, B.; Nicoloso, M.S.; Schiappacassi, M.; Vecchione, A.; Spessotto, P.; Morrione, A.; Canzonieri, V.; Colombatti, A. p27(Kip1)-stathmin interaction influences sarcoma cell migration and invasion. Cancer Cell 2005, 7, 51-63. [CrossRef]

179. Rana, S.; Maples, P.B.; Senzer, N.; Nemunaitis, J. Stathmin 1: A novel therapeutic target for anticancer activity. Exp. Rev. Anticancer Ther. 2008, 8, 1461-1470. [CrossRef]

180. Suzuki, K.; Watanabe, A.; Araki, K.; Yokobori, T.; Harimoto, N.; Gantumur, D.; Hagiwara, K.; Yamanaka, T.; Ishii, N.; Tsukagoshi, M.; et al. High STMN1 Expression Is Associated with Tumor Differentiation and Metastasis in Clinical Patients with Pancreatic Cancer. Anticancer Res. 2018, 38, 939-944. [CrossRef] 
181. Osone, K.; Yokobori, T.; Katayama, C.; Takahashi, R.; Kato, R.; Tatsuski, H.; Takada, T.; Yajima, R.; Motegi, Y.; Ogawa, H.; et al. STMN1 accumulation is associated with dysplastic and neoplastic lesions in patients with ulcerative colitis. Oncol. Lett. 2019, 18, 4712-4718. [CrossRef]

182. Liu, J.; Cao, J.; Zhao, X. miR-221 facilitates the TGFbeta1-induced epithelial-mesenchymal transition in human bladder cancer cells by targeting STMN1. BMC Urol. 2015, 15, 36. [CrossRef]

183. Yang, Y.; Wu, F.; Zhang, J.; Sun, R.; Li, F.; Li, Y.; Chang, S.; Wang, L.; Wang, X.; Liu, L.; et al. EGR1 interacts with DNMT3L to inhibit the transcription of miR-195 and plays an anti-apoptotic role in the development of gastric cancer. J. Cell. Mol. Med. 2019, 23, 7372-7381. [CrossRef] [PubMed]

184. Li, L.; Ameri, A.H.; Wang, S.; Jansson, K.H.; Casey, O.M.; Yang, Q.; Beshiri, M.L.; Fang, L.; Lake, R.G.; Agarwal, S.; et al. EGR1 regulates angiogenic and osteoclastogenic factors in prostate cancer and promotes metastasis. Oncogene 2019, 38, 6241-6255. [CrossRef] [PubMed]

185. Zhu, W.; Long, J.L.; Yin, Y.T.; Guo, H.N.; Jiang, E.P.; Li, Y.L.; He, Q.L.; Zeng, C.; Sun, Y.Q. MicroRNA-34a suppresses the invasion and migration of colorectal cancer cells by enhancing EGR1 and inhibiting vimentin. Exp. Ther. Med. 2019, 18, 2459-2466. [CrossRef] [PubMed]

186. Yan, L.; Wang, Y.; Liang, J.; Liu, Z.; Sun, X.; Cai, K. MiR-301b promotes the proliferation, mobility, and epithelial-to-mesenchymal transition of bladder cancer cells by targeting EGR1. Biochem. Cell Biol. 2017, 95, 571-577. [CrossRef]

187. Huang, M.; Prendergast, G. RhoB in cancer suppression. Histol. Histopathol. 2006, 21, 6.

188. Zhou, J.; Zhu, Y.; Zhang, G.; Liu, N.; Sun, L.; Liu, M.; Qiu, M.; Luo, D.; Tang, Q.; Liao, Z. A distinct role of RhoB in gastric cancer suppression. Int. J. Cancer 2011, 128, 1057-1068. [CrossRef]

189. Bousquet, E.; Calvayrac, O.; Mazieres, J.; Lajoie-Mazenc, I.; Boubekeur, N.; Favre, G.; Pradines, A. RhoB loss induces Rac1-dependent mesenchymal cell invasion in lung cells through PP2A inhibition. Oncogene 2016, 35, 1760-1769. [CrossRef]

190. Bi, J.; Liu, H.; Dong, W.; Xie, W.; He, Q.; Cai, Z.; Huang, J.; Lin, T. Circular RNA circ-ZKSCAN1 inhibits bladder cancer progression through miR-1178-3p/p21 axis and acts as a prognostic factor of recurrence. Mol. Cancer 2019, 18, 133. [CrossRef]

191. Chen, H.; Toyooka, S.; Gazdar, A.F.; Hsieh, J.-T. Epigenetic regulation of a novel tumor suppressor gene (hDAB2IP) in prostate cancer cell lines. J. Biol. Chem. 2003, 278, 3121-3130. [CrossRef]

192. Shen, Y.J.; Kong, Z.L.; Wan, F.N.; Wang, H.K.; Bian, X.J.; Gan, H.L.; Wang, C.F.; Ye, D.W. Downregulation of DAB2IP results in cell proliferation and invasion and contributes to unfavorable outcomes in bladder cancer. Cancer Sci. 2014, 105, 704-712. [CrossRef] [PubMed]

193. Wu, K.; Wang, B.; Chen, Y.; Zhou, J.; Huang, J.; Hui, K.; Zeng, J.; Zhu, J.; Zhang, K.; Li, L.; et al. DAB2IP regulates the chemoresistance to pirarubicin and tumor recurrence of non-muscle invasive bladder cancer through STAT3/Twist1/P-glycoprotein signaling. Cell. Signal. 2015, 27, 2515-2523. [CrossRef] [PubMed]

194. Huang, J.; Wang, B.; Hui, K.; Zeng, J.; Fan, J.; Wang, X.; Hsieh, J.T.; He, D.; Wu, K. miR-92b targets DAB2IP to promote EMT in bladder cancer migration and invasion. Oncol. Rep. 2016, 36, 1693-1701. [CrossRef] [PubMed]

195. Jiang, M.C.; Ni, J.J.; Cui, W.Y.; Wang, B.Y.; Zhuo, W. Emerging roles of lncRNA in cancer and therapeutic opportunities. Am. J. Cancer Res. 2019, 9, 1354-1366.

196. Liang, Z.X.; Liu, H.S.; Wang, F.W.; Xiong, L.; Zhou, C.; Hu, T.; He, X.W.; Wu, X.J.; Xie, D.; Wu, X.R.; et al. LncRNA RPPH1 promotes colorectal cancer metastasis by interacting with TUBB3 and by promoting exosomes-mediated macrophage M2 polarization. Cell Death Dis. 2019, 10, 829. [CrossRef]

197. Yang, W.; Xu, X.; Hong, L.; Wang, Q.; Huang, J.; Jiang, L. Upregulation of IncRNA GAS5 inhibits the growth and metastasis of cervical cancer cells. J. Cell. Physiol. 2019, 234, 23571-23580. [CrossRef]

198. López-Urrutia, E.; Montes, L.P.B.; de Guevara Cervantes, D.L.; Pérez-Plasencia, C.; Campos-Parra, A.D. Crosstalk between long non-coding RNAs, micro-RNAs and mRNAs: Deciphering molecular mechanisms of master regulators in cancer. Front. Oncol. 2019, 9. [CrossRef]

199. Wilusz, J.E.; Sunwoo, H.; Spector, D.L. Long noncoding RNAs: Functional surprises from the RNA world. Genes Dev. 2009, 23, 1494-1504. [CrossRef]

200. Mercer, T.R.; Dinger, M.E.; Mattick, J.S. Long non-coding RNAs: Insights into functions. Nat. Rev. Genet. 2009, 10, 155-159. [CrossRef] 
201. Feng, C.; Zhao, Y.; Li, Y.; Zhang, T.; Ma, Y.; Liu, Y. LncRNA MALAT1 Promotes Lung Cancer Proliferation and Gefitinib Resistance by Acting as a miR-200a Sponge. Archivos de Bronconeumologia 2019, 55, 627-633. [CrossRef]

202. Zhao, Y.; Feng, C.; Li, Y.; Ma, Y.; Cai, R. LncRNA H19 promotes lung cancer proliferation and metastasis by inhibiting miR-200a function. Mol. Cell. Biochem. 2019, 460, 1-8. [CrossRef] [PubMed]

203. Wang, X.; Lai, Q.; He, J.; Li, Q.; Ding, J.; Lan, Z.; Gu, C.; Yan, Q.; Fang, Y.; Zhao, X.; et al. LncRNA SNHG6 promotes proliferation, invasion and migration in colorectal cancer cells by activating TGF- $\beta /$ Smad signaling pathway via targeting UPF1 and inducing EMT via regulation of ZEB1. Int. J. Med. Sci. 2019, 16, 51-59. [CrossRef] [PubMed]

204. Wang, C.; Tao, W.; Ni, S.; Chen, Q. Upregulation of lncRNA snoRNA host gene 6 regulates NUAK family SnF1-like kinase-1 expression by competitively binding microRNA-125b and interacting with Snail1/2 in bladder cancer. J. Cell. Biochem. 2019, 120, 357-367. [CrossRef] [PubMed]

205. Luo, M.; Li, Z.; Wang, W.; Zeng, Y.; Liu, Z.; Qiu, J. Long non-coding RNA H19 increases bladder cancer metastasis by associating with EZH2 and inhibiting E-cadherin expression. Cancer Lett. 2013, 333, $213-221$. [CrossRef] [PubMed]

206. Zhu, Z.; Xu, L.; Wan, Y.; Zhou, J.; Fu, D.; Chao, H.; Bao, K.; Zeng, T. Inhibition of E-cadherin expression by lnc-RNA H19 to facilitate bladder cancer metastasis. Cancer Biomark. Sect. A Dis. Mark. 2018, 22, $275-281$. [CrossRef] [PubMed]

207. Lv, M.; Zhong, Z.; Huang, M.; Tian, Q.; Jiang, R.; Chen, J. lncRNA H19 regulates epithelial-mesenchymal transition and metastasis of bladder cancer by miR-29b-3p as competing endogenous RNA. Biochimica et Biophysica Acta Mol. Cell Res. 2017, 1864, 1887-1899. [CrossRef]

208. Miao, L.; Liu, H.Y.; Zhou, C.; He, X. LINC00612 enhances the proliferation and invasion ability of bladder cancer cells as ceRNA by sponging miR-590 to elevate expression of PHF14. J. Exp. Clin. Cancer Res. 2019, 38, 143. [CrossRef]

209. Mao, W.; Huang, X.; Wang, L.; Zhang, Z.; Liu, M.; Li, Y.; Luo, M.; Yao, X.; Fan, J.; Geng, J. Circular RNA hsa_circ_0068871 regulates FGFR3 expression and activates STAT3 by targeting miR-181a-5p to promote bladder cancer progression. J. Exp. Clin. Cancer Res. 2019, 38, 169. [CrossRef]

210. Bi, J.; Liu, H.; Cai, Z.; Dong, W.; Jiang, N.; Yang, M.; Huang, J.; Lin, T. Circ-BPTF promotes bladder cancer progression and recurrence through the miR-31-5p/RAB27A axis. Aging 2018, 10, 1964-1976. [CrossRef]

211. Yang, C.; Yuan, W.; Yang, X.; Li, P.; Wang, J.; Han, J.; Tao, J.; Li, P.; Yang, H.; Lv, Q.; et al. Circular RNA circ-ITCH inhibits bladder cancer progression by sponging miR-17/miR-224 and regulating p21, PTEN expression. Mol. Cancer 2018, 17, 19. [CrossRef]

212. Yan, D.; Dong, W.; He, Q.; Yang, M.; Huang, L.; Kong, J.; Qin, H.; Lin, T.; Huang, J. Circular RNA circPICALM sponges miR-1265 to inhibit bladder cancer metastasis and influence FAK phosphorylation. EBioMedicine 2019, 48, 316-331. [CrossRef] [PubMed]

213. Liu, H.; Chang, J.K.; Hou, J.Q.; Zhao, Z.H.; Zhang, L.D. Inhibition of miR-221 influences bladder cancer cell proliferation and apoptosis. Eur. Rev. Med. Pharm. Sci. 2017, 21, 3193-3199.

214. Fu, B.; Wang, Y.; Zhang, X.; Lang, B.; Zhou, X.; Xu, X.; Zeng, T.; Liu, W.; Zhang, X.; Guo, J.; et al. MiR-221-induced PUMA silencing mediates immune evasion of bladder cancer cells. Int. J. Oncol. 2015, 46, 1169-1180. [CrossRef] [PubMed]

215. Su, Y.; Feng, W.; Shi, J.; Chen, L.; Huang, J.; Lin, T. circRIP2 accelerates bladder cancer progression via miR-1305/Tgf- $\beta 2 /$ smad3 pathway. Mol. Cancer 2020, 19, 23. [CrossRef] [PubMed]

216. Gong, T.-T.; Liu, X.-D.; Zhan, Z.-P.; Wu, Q.-J. Sulforaphane enhances the cisplatin sensitivity through regulating DNA repair and accumulation of intracellular cisplatin in ovarian cancer cells. Exp. Cell Res. 2020, 393, 112061. [CrossRef] [PubMed]

217. Calcabrini, C.; Maffei, F.; Turrini, E.; Fimognari, C. Sulforaphane Potentiates Anticancer Effects of Doxorubicin and Cisplatin and Mitigates Their Toxic Effects. Front. Pharmacol. 2020, 11, 567. [CrossRef]

218. Shan, Y.; Zhang, L.; Bao, Y.; Li, B.; He, C.; Gao, M.; Feng, X.; Xu, W.; Zhang, X.; Wang, S. Epithelial-mesenchymal transition, a novel target of sulforaphane via COX-2/MMP2, 9/Snail, ZEB1 and miR-200c/ZEB1 pathways in human bladder cancer cells. J. Nutr. Biochem. 2013, 24, 1062-1069. [CrossRef]

219. Gakis, G. The role of inflammation in bladder cancer. In Inflammation and Cancer; Springer: New York, NY, USA, 2014; pp. 183-196. 
220. Masson-Lecomte, A.; Rava, M.; Real, F.X.; Hartmann, A.; Allory, Y.; Malats, N. Inflammatory biomarkers and bladder cancer prognosis: A systematic review. Eur. Urol. 2014, 66, 1078-1091. [CrossRef]

221. Patel, R.; Baker, S.S.; Liu, W.; Desai, S.; Alkhouri, R.; Kozielski, R.; Mastrandrea, L.; Sarfraz, A.; Cai, W.; Vlassara, H. Effect of dietary advanced glycation end products on mouse liver. PLoS ONE 2012, 7. [CrossRef]

222. Galdiero, M.R.; Garlanda, C.; Jaillon, S.; Marone, G.; Mantovani, A. Tumor associated macrophages and neutrophils in tumor progression. J. Cell. Physiol. 2013, 228, 1404-1412. [CrossRef]

223. Li, F.; Shanmugam, M.K.; Chen, L.; Chatterjee, S.; Basha, J.; Kumar, A.P.; Kundu, T.K.; Sethi, G. Garcinol, a polyisoprenylated benzophenone modulates multiple proinflammatory signaling cascades leading to the suppression of growth and survival of head and neck carcinoma. Cancer Prev. Res. 2013, 6, 843-854. [CrossRef] [PubMed]

224. Sawhney, M.; Rohatgi, N.; Kaur, J.; Shishodia, S.; Sethi, G.; Gupta, S.D.; Deo, S.V.; Shukla, N.K.; Aggarwal, B.B.; Ralhan, R. Expression of NF-kappaB parallels COX-2 expression in oral precancer and cancer: Association with smokeless tobacco. Int. J. Cancer 2007, 120, 2545-2556. [CrossRef] [PubMed]

225. Ahn, K.S.; Sethi, G.; Jain, A.K.; Jaiswal, A.K.; Aggarwal, B.B. Genetic deletion of NAD(P)H:Quinone oxidoreductase 1 abrogates activation of nuclear factor- $k \mathrm{~B}, \mathrm{I} \kappa \mathrm{B} \alpha$ kinase, $\mathrm{c}-J u n \mathrm{~N}$-terminal kinase, Akt, $\mathrm{p} 38$, and p44/42 mitogen-activated protein kinases and potentiates apoptosis. J. Biol. Chem. 2006, 281, 19798-19808. [CrossRef] [PubMed]

226. Siveen, K.S.; Mustafa, N.; Li, F.; Kannaiyan, R.; Ahn, K.S.; Kumar, A.P.; Chng, W.J.; Sethi, G. Thymoquinone overcomes chemoresistance and enhances the anticancer effects of bortezomib through abrogation of NF-kappaB regulated gene products in multiple myeloma xenograft mouse model. Oncotarget 2014, 5, 634-648. [CrossRef]

227. Zhang, Q.; Mao, Z.; Sun, J. NF-кB inhibitor, BAY11-7082, suppresses M2 tumor-associated macrophage induced EMT potential via miR-30a/NF-kB/Snail signaling in bladder cancer cells. Gene 2019, 710, 91-97. [CrossRef]

228. Tailor, D.; Hahm, E.-R.; Kale, R.K.; Singh, S.V.; Singh, R.P. Sodium butyrate induces DRP1-mediated mitochondrial fusion and apoptosis in human colorectal cancer cells. Mitochondrion 2014, 16, 55-64. [CrossRef]

229. Salimi, V.; Shahsavari, Z.; Safizadeh, B.; Hosseini, A.; Khademian, N.; Tavakoli-Yaraki, M. Sodium butyrate promotes apoptosis in breast cancer cells through reactive oxygen species (ROS) formation and mitochondrial impairment. Lipids Health Dis. 2017, 16, 208. [CrossRef]

230. Kuefer, R.; Hofer, M.; Altug, V.; Zorn, C.; Genze, F.; Kunzi-Rapp, K.; Hautmann, R.; Gschwend, J. Sodium butyrate and tributyrin induce in vivo growth inhibition and apoptosis in human prostate cancer. Br. J. Cancer 2004, 90, 535-541. [CrossRef]

231. Maruyama, T.; Yamamoto, S.; Qiu, J.; Ueda, Y.; Suzuki, T.; Nojima, M.; Shima, H. Apoptosis of bladder cancer by sodium butyrate and cisplatin. J. Infect. Chemother. 2012, 18, 288-295. [CrossRef]

232. Wang, F.; Wu, H.; Fan, M.; Yu, R.; Zhang, Y.; Liu, J.; Zhou, X.; Cai, Y.; Huang, S.; Hu, Z.; et al. Sodium butyrate inhibits migration and induces AMPK-mTOR pathway-dependent autophagy and ROS-mediated apoptosis via the miR-139-5p/Bmi-1 axis in human bladder cancer cells. FASEB J. 2020, 34, 4266-4282. [CrossRef]

233. Han, Y.; Chen, P.; Zhang, Y.; Lu, W.; Ding, W.; Luo, Y.; Wen, S.; Xu, R.; Liu, P.; Huang, P. Synergy between Auranofin and Celecoxib against Colon Cancer In Vitro and In Vivo through a Novel Redox-Mediated Mechanism. Cancers 2019, 11. [CrossRef] [PubMed]

234. Velmurugan, B.K.; Hua, C.H.; Tsai, M.H.; Lee, C.P.; Chung, C.M.; Ko, Y.C. Combination of celecoxib and calyculin-A inhibits epithelial-mesenchymal transition in human oral cancer cells. Biotech. Histochem. 2020, 95, 1-8. [CrossRef] [PubMed]

235. Liu, X.; Wu, Y.; Zhou, Z.; Huang, M.; Deng, W.; Wang, Y.; Zhou, X.; Chen, L.; Li, Y.; Zeng, T.; et al. Celecoxib inhibits the epithelial-to-mesenchymal transition in bladder cancer via the miRNA-145/TGFBR2/Smad3 axis. Int. J. Mol. Med. 2019, 44, 683-693. [CrossRef] [PubMed]

236. Tran, M.N.; Choi, W.; Wszolek, M.F.; Navai, N.; Lee, I.L.; Nitti, G.; Wen, S.; Flores, E.R.; Siefker-Radtke, A.; Czerniak, B.; et al. The p63 protein isoform $\triangle \mathrm{Np} 63 \alpha$ inhibits epithelial-mesenchymal transition in human bladder cancer cells: Role of MIR-205. J. Biol. Chem. 2013, 288, 3275-3288. [CrossRef]

237. Wang, J.; Zhang, H.; Situ, J.; Li, M.; Sun, H. KCNQ1OT1 aggravates cell proliferation and migration in bladder cancer through modulating miR-145-5p/PCBP2 axis. Cancer Cell Int. 2019, 19, 325. [CrossRef] 
238. Zhan, Y.; Chen, Z.; Li, Y.; He, A.; He, S.; Gong, Y.; Li, X.; Zhou, L. Long non-coding RNA DANCR promotes malignant phenotypes of bladder cancer cells by modulating the miR-149/MSI2 axis as a ceRNA. J. Exp. Clin. Cancer Res. 2018, 37, 273. [CrossRef]

239. Liao, C.; Long, Z.; Zhang, X.; Cheng, J.; Qi, F.; Wu, S.; Huang, T. LncARSR sponges miR-129-5p to promote proliferation and metastasis of bladder cancer cells through increasing SOX4 expression. Int. J. Biol. Sci. 2020, 16, 1-11. [CrossRef]

240. Xu, R.; Zhu, X.; Chen, F.; Huang, C.; Ai, K.; Wu, H.; Zhang, L.; Zhao, X. LncRNA XIST/miR-200c regulates the stemness properties and tumourigenicity of human bladder cancer stem cell-like cells. Cancer Cell Int. 2018, 18, 41. [CrossRef]

241. Luo, J.; Chen, J.; Li, H.; Yang, Y.; Yun, H.; Yang, S.; Mao, X. LncRNA UCA1 promotes the invasion and EMT of bladder cancer cells by regulating the miR-143/HMGB1 pathway. Oncol. Lett. 2017, 14, 5556-5562. [CrossRef]

242. Xue, M.; Pang, H.; Li, X.; Li, H.; Pan, J.; Chen, W. Long non-coding RNA urothelial cancer-associated 1 promotes bladder cancer cell migration and invasion by way of the hsa-miR-145-ZEB1/2-FSCN1 pathway. Cancer Sci. 2016, 107, 18-27. [CrossRef]

243. Li, W.; Li, Y.; Ma, W.; Zhou, J.; Sun, Z.; Yan, X. Long noncoding RNA AC114812.8 promotes the progression of bladder cancer through miR-371b-5p/FUT4 axis. Biomed. Pharm. 2020, 121, 109605. [CrossRef] [PubMed]

244. Tan, J.; Qiu, K.; Li, M.; Liang, Y. Double-negative feedback loop between long non-coding RNA TUG1 and miR-145 promotes epithelial to mesenchymal transition and radioresistance in human bladder cancer cells. FEBS Lett. 2015, 589, 3175-3181. [CrossRef] [PubMed]

245. Li, Z.; Hong, S.; Liu, Z. LncRNA LINC00641 predicts prognosis and inhibits bladder cancer progression through miR-197-3p/KLF10/PTEN/PI3K/AKT cascade. Biochem. Biophys. Res. Commun. 2018, 503, 1825-1829. [CrossRef] [PubMed]

246. Wu, X.; Chen, B.; Shi, H.; Zhou, J.; Zhou, F.; Cao, J.; Sun, X. miR-758-3p suppresses human bladder cancer cell proliferation, migration and invasion by targeting NOTCH2. Exp. Ther. Med. 2019, 17, 4273-4278. [CrossRef] [PubMed]

247. Zhang, Z.; Qin, H.; Jiang, B.; Chen, W.; Cao, W.; Zhao, X.; Yuan, H.; Qi, W.; Zhuo, D.; Guo, H. miR-30e-5p suppresses cell proliferation and migration in bladder cancer through regulating metadherin. J. Cell. Biochem. 2019, 120, 15924-15932. [CrossRef] [PubMed]

248. Liu, Y.; Liu, T.; Jin, H.; Yin, L.; Yu, H.; Bi, J. MiR-411 suppresses the development of bladder cancer by regulating ZnT1. Oncotarget. Ther. 2018, 11, 8695-8704. [CrossRef] 